\title{
Simplified performance assessment methodology for addressing soil quality of nature-based solutions
}

\author{
Ryad Bouzouidja ${ }^{1,2,3,4}$ (1D $\cdot$ Béatrice Béchet ${ }^{3,4}$ - Jitka Hanzlikova ${ }^{5,6} \cdot$ Michal Sněhota $^{4,5}$. Cécile Le Guern ${ }^{4,7}$. \\ Hervé Capiaux $^{2,4}$ • Liliane Jean-Soro ${ }^{3,4}$ - Rémy Claverie ${ }^{8}$ - Sophie Joimel ${ }^{9} \cdot$ Christophe Schwartz $^{10,11} \cdot$ René Guénon $^{1,4}$. \\ Flora Szkordilisz ${ }^{12,13} \cdot$ Barnabas Körmöndi $^{12}$ - Marjorie Musy ${ }^{4,14}$ • Patrice Cannavo ${ }^{1,4} \cdot$ Thierry Lebeau $^{2,4}$
}

Received: 10 February 2020 / Accepted: 19 July 2020 / Published online: 30 July 2020

(C) The Author(s) 2020

\begin{abstract}
Purpose In urban areas, soil functions are deeply impacted by all human activities, e.g., water infiltration, carbon storage, and chemical substances degradation potential. In this context, nature-based solutions (NBS) are assumed to deliver multiple environmental benefits for soil quality improvement. The H2020 Nature4Cities project (N4C) offers the framework to develop physical, chemical, and microbiological indicators to the performance assessment for addressing NBS soil quality (performance assessment of soil quality) to be included in a tool-box designed for architects or municipalities.

Materials and methods A simplified performance assessment methodology was developed for addressing NBS soil quality. It is based on the comparison of physical, chemical, and biological characteristics to soil reference baseline. In this setting, we present here the results obtained from case studies selected in three European cities (Nantes (F), Nancy (F), Bustehrad (CR)) to test the methodology. The case studies correspond to three different NBSs: former market turned into gardening areas (FMG), green roofs (GR), and urban allotment gardens (UAG). The performance assessment was based on two criteria: (1) soil fertility and (2) soil contamination.

Results and discussion The basic soil properties (e.g., pH, bulk density) and soil fertility (e.g., soil organic matter (SOM)) for the two open soil NBS (FMG and UAGs) are equivalent to cultivated soils. Those of GR are highly controlled by the type of natural materials used in the substrate. Concerning contamination, the soil quality of FMG was shown to be significantly impacted by former agricultural practices (pesticide residues, trace metals (TE)). Measured molecular biomass of FMG was compared with
\end{abstract}

Responsible editor: Kye-Hoon John Kim

Electronic supplementary material The online version of this article (https://doi.org/10.1007/s11368-020-02731-y) contains supplementary material, which is available to authorized users.

Ryad Bouzouidja

ryad.bouzouidja@gmail.com

1 EPHOR, Institut Agro, 49045 Angers, France

2 Université de Nantes, LPG (Laboratoire de Planétologie et Géodynamique), UMR 6112 CNRS, 2 rue de la Houssinière, BP 92208, 44322 Nantes cedex 3, France

3 GERS-LEE, Univ Gustave Eiffel, IFSTTAR, F-44344 Bouguenais, France

4 Institut de Recherche en Sciences et Techniques de la Ville IRSTV, CNRS, 1 rue de la Noë, 44321 Nantes Cedex 3, France

5 Faculty of Civil Engineering, Czech Technical University in Prague, Thákurova 7, 16629 Prague, Czech Republic

6 University Centre for Energy Efficient Buildings, Czech Technical University in Prague, Trinecka 1024, 273

43 Bustehrad, Czech Republic
7 BRGM - Bureau de Recherches Géologiques et Minières (BRGM), 1 Rue des Saumonières, 44000 Nantes, France

8 Cerema DTer-Est/LRN, 71 rue de la grande haie, F-54510 Tomblaine, France

9 UMR ECOSYS, INRAE, AgroParisTech, Université Paris-Saclay, 78850 Thiverval-Grignon, France

10 Université de Lorraine, Laboratoire Sols et Environnement, UMR 1120, 54500 Vandœuvre-lès-Nancy, France

11 INRA, Laboratoire Sols et Environnement, UMR 1120, 54500 Vandœuvre-lès-Nancy, France

12 MUTK, Hungarian Urban Knowledge Centre, Liliom u. 48, Budapest 1094, Hungary

13 University of Debrecen, Earth Sciences PhD Program, Egyetem tér 1, Debrecen 4010, Hungary

14 Cerema Ouest, Equipe Projet de Recherche BPE, F-44000 Nantes, France 
predictive molecular biomass (determined according to the soil physicochemical properties). Data showed that 12 of the 14 measured plots are classified as altered or very altered soils with regard to this parameter. TE in UAGs soils exhibit various concentrations, depending on former land use, cultural practices, and geological contexts.

Conclusions In conclusion, the study showed that soil fertility is a rather interesting tool in the evaluation of urban soil quality. Nevertheless, basic soil properties seem to be influenced by the effects of trace element and pesticide contamination. The presence of NBSs seems to have a favorable impact (e.g., filtration of pollutants). Inappropriate management of urban soils can lead to a decrease in soil quality and thus influence the current major issues (e.g., carbon sequestration, contamination of urban spaces by organic, and inorganic pollutants).

Keywords Nature4Cities · Biophysicochemical characteristics $\cdot$ Green roof $\cdot$ Urban allotment gardens $\cdot$ Former gardening areas . Trace element $\cdot$ Soil contamination

\section{Introduction}

The global human population is forecasted to reach 9.1 billion by 2050, 34\% more than in 2017 (United Nations 2018). In a context of rapid urbanization, megacities are facing major environmental issues (e.g., pollution, urban heat island) (Kelly 2003; Levin et al. 2017). The development of sustainable and resilient cities requires therefore new solutions and concepts, such as nature-based solutions (NBS) (referred to hereafter as NBS(s)). NBS was defined as a solution using nature to meet challenges and more specifically to conserve biodiversity (European Commission 2016). The current literature refers to NBS as an alternative to tackle many societal challenges: climate mitigation, water management, maintenance of biodiversity, reduction of energy consumption, economic, and social aspects (European Commission 2016; Alberti 2017; Faivre et al. 2017). As NBSs are assumed to deliver multiple environmental benefits, they are intended to improve soil quality, which will enhance soil functions that are deeply impacted by all human activities (Rees et al. 2019).

Urban soil quality has become an increasingly urgent challenge at city scale, as confirmed by researchers and urban planners (De Kimpe and Morel 2000; Levin et al. 2017). Urban soils are known to have peculiar characteristics such as unpredictable layer organization, poor structure, and sometimes, high concentrations of persistent contaminants such as trace elements (TE) (Kabata-Pendias 2010; Bouzouidja et al. 2019). The soil physical and chemical properties (soil texture, porosity, hydrodynamic properties, $\mathrm{pH}$, carbonates, and cation exchange capacity) are well known to directly control soil biological activities in the case of urban areas (Pouyat et al. 2010; Joimel et al. 2016). Taking into account urban soil management in urban planning strategy would contribute to the mitigation of some major environmental issues (e.g., loss of organic carbon).

The quality of urban soil can be described as its ability to fulfill environmental functions and perform ecosystem services (Morel et al. 2014). Large variety of soils have the capacity to retain and filter rainwater (Byeon 2006; Mentens et al. 2006; Schwager et al. 2015; Bouzouidja et al. 2018b), to absorb and retain various pollutants, such as pesticides (Wołejko et al. 2019), organic pollutants (Dagois et al. 2017), and heavy metals. Arora et al. (2019) argued that the overdose of some pesticides has negative effects on soil microorganisms, the latter playing an important part in keeping soils healthy and conserving of the functions of the ecosystems. Pesticides that disturb the functioning of microorganisms in the soil have the potential to affect the overall nutritional quality of the soil and the soil environment (Kumar et al. 2012). Evaluating the quality of urban soil is crucial to identify changes in land resources and their potential in being vegetated. Soil properties are mainly influenced by natural factors and anthropogenic activities acting at different spatial and temporal scales. Therefore, these properties should be correlated according to spatial scale (Castrignanò et al. 2000). The main feature of urban soils is the high spatial heterogeneity (centimeter to decimeter) of their physical and chemical properties (Béchet et al. 2009; Béchet et al. 2018).

Urban soils support buildings (residential, commercial, and industrial), infrastructure (roads and railways), recreational facilities (such as sports grounds), vegetation on buildings (e.g., green roof (GR)), or the production of biomass (urban allotment gardens (UAG), market gardening areas (FMG) or parks) within a restricted area. These numerous uses, frequently superimposed over time, can play a role as interface and base for a large number of biophysical-chemical processes (Scharenbroch et al. 2005). Therefore, in order to develop sustainable management of urban areas and to assist urban managers in their decision-making, it is necessary, in the specific case of NBS, to introduce streamlined approaches to evaluate their achievements, considering the footprint of the soil subfund.

To assess urban challenges, two ways are considered (the way of the soil scientists and NBS supporters): (i) some studies consider urban soils properties as a solution to tackle the urban challenges (e.g., climate regulation, storm water management), but these challenges are not connected to each other. The Snowman MCA project (Volchko et al. 2013) implemented a 
multicriteria analysis assessing soil management and alternatives for sustainable remediation. Other methods allow soil evaluation on the basis of selected indicators. In the Uqualisol-ZU project (Gessol; Keller et al. 2014), the multifunctional character of the soil provides guidance for the choice of land-use. In the European ENVASSO project, other indicators were selected for their ability to assess, not directly soil functions, but threats to soil; (ii) Others studies consider ecosystem services provided by the presence of nature within the urban environment (e.g., NATURVATION (Bulkeley and Raven 2017), EKLIPSE (Dicks et al. 2017; Watt et al. 2019)). For example, the EKLIPSE project intends to build an innovative, streamlined, and independent support mechanism to inform European policy-making on biodiversity and associated ecosystem services. Nevertheless, the consideration of the soil is little discussed. Thus, taking soil into account in decision support requires the elaboration of simple indicators that are easy to assess and as generic as possible. Kabisch et al. (2016) argued that the expansion of indicators can help to assess and demonstrate the usefulness and effectiveness of NBSs and enhance the measurability of their effects. In addition, indicators can help to systematically evaluate NBS initiatives and increase comparability and measurability, thus adding to the base of evidence for NBS. Although, Haase et al. (2014) explained that despite the growing interest observed for urban challenges rendered by the urban environment, there are still very few publications dealing with these challenges and urban soils.

In this context, the ongoing H2020 Nature4Cities project (N4C) (Nature4Cities 2016) offers the framework to develop physical, chemical, and microbiological indicators for performance assessment of NBS addressing soil quality to be included in a toolbox designed for decisionmakers. A simplified methodology including key performance indicators (UPIs) and ranking scores was developed to be applied to N4C pilot cities. The indicators help both in the initial diagnosis of the quality of a soil or material in the NBS selection phase, with regard to one or more challenges, and in the evaluation of the performance of a postimplementation NBS (monitoring stage). As the rigorous UPIs selection process results in a short list of indicators, additional indicators are suggested to achieve the assessment of NBS soil quality. The robustness of methodologies is evaluated for three case studies selected in Europe (France and Czech Republic) where NBSs are established: FMG, GR, and UAG. This paper aims at (i) analyzing soil biophysicochemical characteristics of the NBSs and comparing to soil reference frame; (ii) understanding how NBSs are likely to play a role by influencing urban soil quality, based on two criteria: (1) soil fertility; (2) soil contamination, without taking the evolution or soil ageing into account; and (iii) the methodology used in the $\mathrm{N} 4 \mathrm{C}$ project has led to a selection of key indicators that need to be validated as such.

\section{Material and methods}

\subsection{N4C project methodology}

The European Nature4Cities (N4C) project (Nature4Cities 2016) is built on structured knowledge based on (i) NBS (technical solutions, performances, examples of application in pioneering projects); (ii) the development of a holistic evaluation method, (iii) the adaptation of existing technologies for urban data management and citizen participation; and (iv) the codevelopment and validation of approaches with pilot cities in Europe. The N4C project also classified NBSs into two broad categories: (i) forms and (ii) strategies (Cerema et al. 2018). In this article, we will only focus on the "forms" category, since the category "strategy" is mainly aimed at the planning area. The category "forms" is divided into three subcategories (water compartment, on the building, on the surface) (Fig.1a).

During this project, we identified and analyzed an extensive set of urban performance indicators (UPIs) for the assessment of urban challenges (UC). Finally, five main topics containing eight UC were defined (Fig. 1b). This UC framework covers NBS impacts on Climate Issues, Water Management, Air Quality, Green Space Management and Biodiversity, Urban Regeneration, Resource Efficiency, Public Health and Well-being, Environmental Justice and Social Cohesion, Urban Planning and Governance, People Security and Green Economy. The use of the selected UPIs is then assessed on case studies in the pilot cities to gauge their usability both in terms of evaluation possibility (for example regarding the availability of the needed data) and in terms of impact on the NBS project (how it can help decision makers). N4C project concentrated on determining and evaluating a basic set of indicators for its UC. Constructed on the expert groups' understanding and literature reviews, all of 110 UPIs were compiled (Green4cities et al. 2018). From an urban soil management point of view, the NBS performance evaluation approach focused on the soil compartment, and more specifically on soil quality indicators, and 11 UPIs were used: (i) simple parameter of intrinsic characterization, (ii) indicator resulting from a pedotransfer functions and compared these to optimal properties (Table 1). For the purposes of this article, we have focused entirely on soil-related indicators. We have used some indicators from the $\mathrm{N} 4 \mathrm{C}$ project: soil organic matter, soil contamination, and soil fertility.

Understanding soil properties (physical, chemical, and biological) is quite difficult for the uninitiated. Therefore, the use of simple concepts is an acceptable alternative. Blanchart et al. (2018) suggested (i) using a restricted number of indicators (set of parameters resulting from measurements and computations), (ii) using a descriptive integrative list of indicators expressing the functioning of soil, (iii) integrating the vertical and horizontal heterogeneities of urban soils, and (iv) using an 
Fig. 1 Schematic diagram of a Nature-Based solution (NBS) classification used in the Nature4Cities (N4C) project (Nature4Cities 2016) adapted from Cerema et al. (2018) and $\mathbf{b}$ the methodology for analyzing the impact of NBS at the urban scale - how to consider the impact of nature on soil management challenge in relation to others challenges. GHG means greenhouse gas emissions. UHI means urban heat island. PET means physiological equivalent temperature. UGSP means urban green space proportion. EUA means energy use in agriculture. DV means diversity of vegetation. BEN means building energy needs. EE means energy efficiency. Qol means quality of life

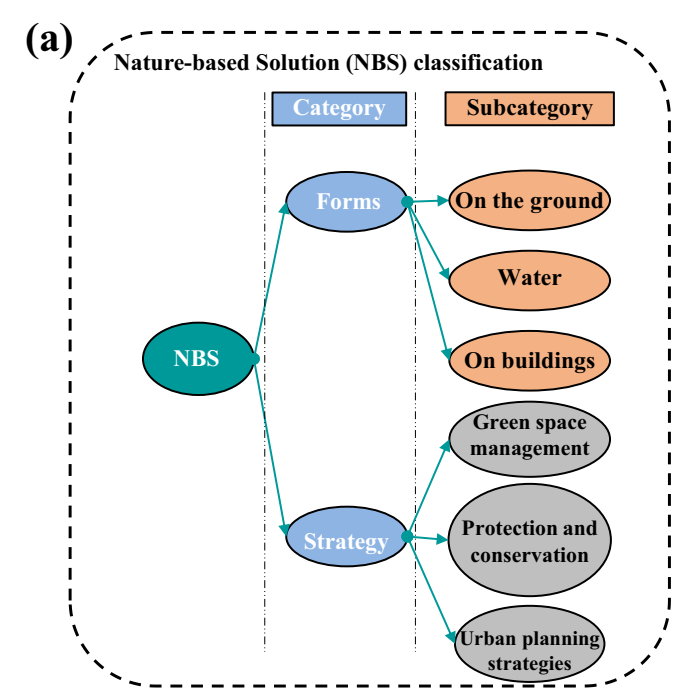

(b)

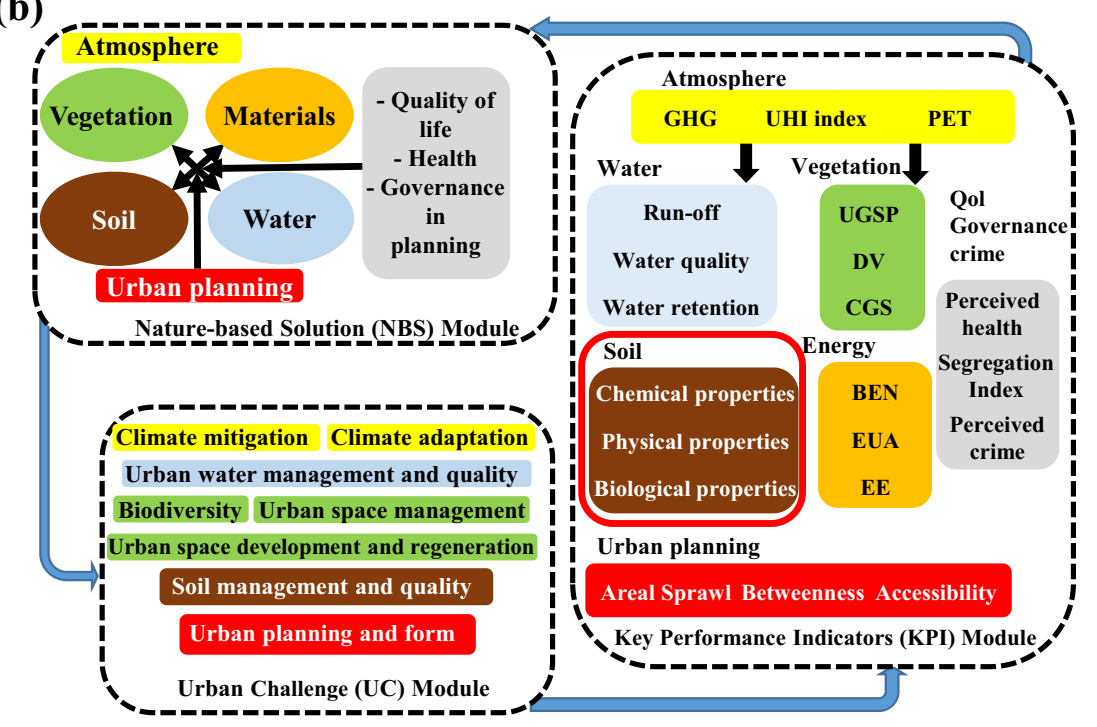

adequate ranking system for each indicator. According to these suggestions, we use soil fertility as a simplification to evaluate urban soil quality. Therefore, we use the physical and chemical soil indicators described by Vidal-Beaudet et al. (2017) to assess soil fertility. The authors determined a set of indicators by combining the interpretation of the agronomical analysis of urban soils and recommendations on soil fertility for a large set of physical indicators (bulk density $\left(\mathrm{D}_{\mathrm{b}}\right)$, soil available water $\left.(\mathrm{SAW})\right)$ and chemical indicators (cation exchange capacity (CEC), Olsen Phosphorus $\left(\mathrm{P}_{2} \mathrm{O}_{5}\right)$, soil organic matter $(\mathrm{SOM})$ and total nitrogen $(\mathrm{TN})$, carbon and nitrogen ratio $(\mathrm{C}: \mathrm{N}), \mathrm{pH}$ of water $\left(\mathrm{pH}_{\mathrm{water}}\right)$, and total carbonates (totCaCO 3$)$ ).

Urban soil fertility was determined assuming that the agronomical properties of NBSs could be interpreted in the same way as those of crop soils. The reference data and indicators for urban soil quality are presented in Table 2 and Table 3. The value of each indicator was ranked using a scoring system. This system includes four classes from 3 to 0 as follows: a score of 3 for optimal quality, and a score of 0 for the worst. Such indicators could be considered as representative of the global soil quality.

\subsection{Description of the case studies in the three European cities}

The three cities selected were Nantes, Nancy (France), and Bustehrad (Czech Republic). They were chosen for their wide range of climatic conditions (oceanic to humid continental climate), geology, population density, and likely sources of pollution.

Located in Nantes (France), urban allotment gardens (UAGs) were chosen based on previous studies performed by Joimel et al. (2016) and Béchet et al. (2018). These UAGs were mainly created on former market gardening areas or agricultural lands. In case of soil contamination, soil precise 


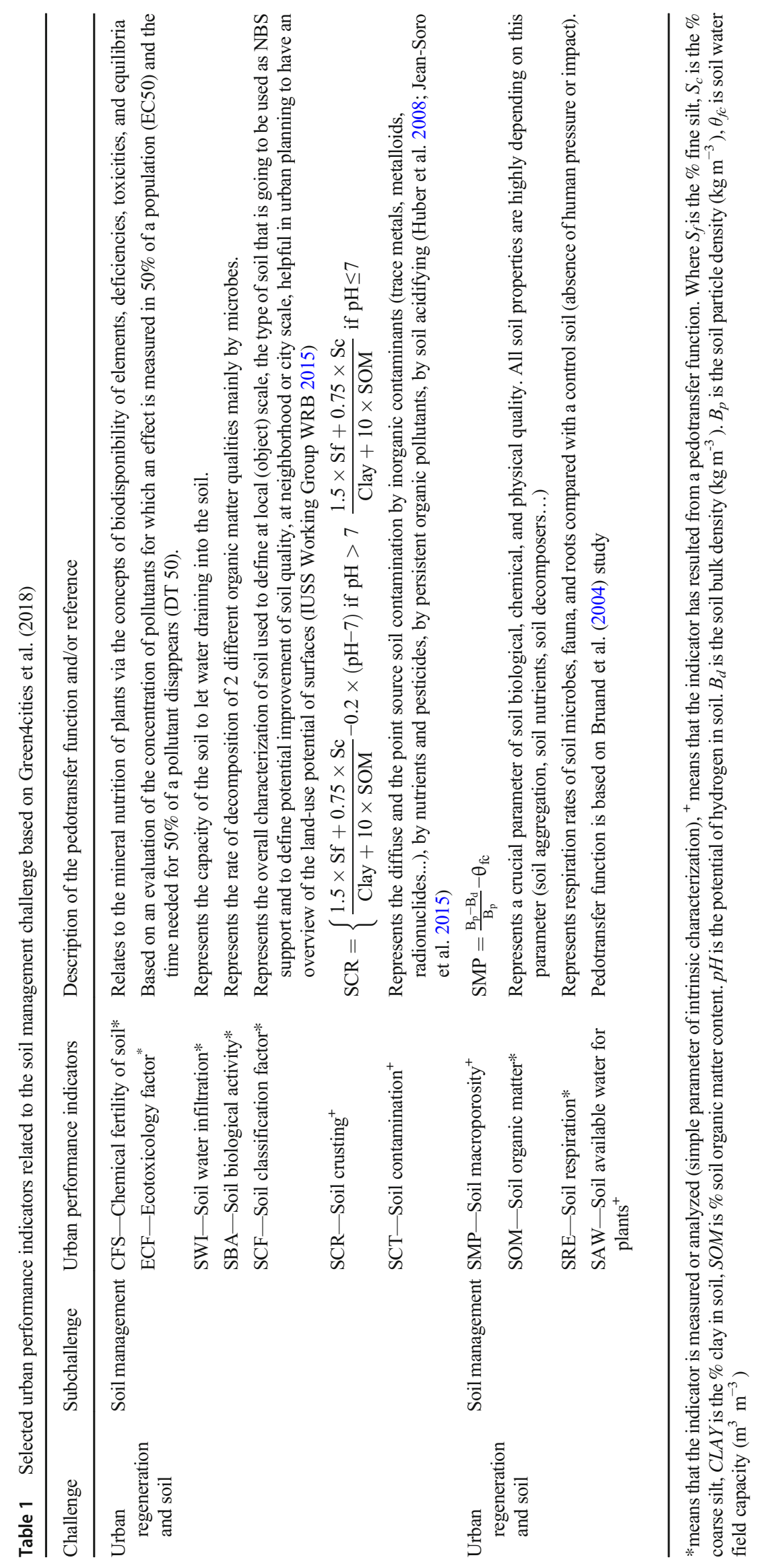


Table 2 Selected physical and chemical quality indicators and classes of values

\begin{tabular}{lllll}
\hline Physical indicators & Units & Score & Range of values & Interpretation \\
\hline Bulk density $\left(\mathrm{D}_{\mathrm{b}}\right)$ & $\mathrm{g} \mathrm{cm}^{-3}$ & 0 & $>1.7$ & Very low \\
& & 1 & 1.5 to 1.7 & Low \\
& & 2 & 1.2 to 1.5 & Too high \\
Soil available water for plants (SAW) & $\mathrm{mm}_{\text {water }} \mathrm{m}_{\text {soil }}{ }^{-1}$ & 0 & $<50$ & Optimal \\
& & 1 & 50 to 100 & Very low \\
& & 2 & 100 to 150 & Low \\
& & 3 & $>150$ & Opderate \\
\end{tabular}

diagnostics were performed and management options were discussed with the city council, the sanitary administration, and the gardeners (Le Guern et al. 2018). Former market gardens (FMGs) were selected based on their history, i.e., past intense market gardening surrounding the Nantes city. Market practices ceased for 5 to 20 years, and the plots became vacant now included in the urban network. Two green roofs (GRs) were selected in Nancy (Eastern France) based on a previous study performed by Schwager et al. (2015) and Bustehrad (Czech Republic) based on their capability to improve several ecosystem services in cities: (i) regulation of local climate and storm water regulation (Mentens et al. 2006; Jelinkova et al.
Table 3 Selected physical and chemical quality indicators and classes of values

\begin{tabular}{|c|c|c|c|c|}
\hline Chemical indicators & Units & Score & Range of values & Interpretation \\
\hline \multirow[t]{4}{*}{ Cation exchange capacity (CEC) } & \multirow[t]{4}{*}{$\mathrm{cmol} \mathrm{kg}^{-1}$} & 0 & $<12$ & Low \\
\hline & & 1 & 12 to 25 & Moderate \\
\hline & & 2 & 25 to 40 & High \\
\hline & & 3 & $>40$ & Very high \\
\hline \multirow[t]{4}{*}{$\mathrm{P}_{2} \mathrm{O}_{5}$} & \multirow[t]{4}{*}{$\mathrm{g} \mathrm{kg}^{-1}$} & 0 & $<0.04$ & Low \\
\hline & & 1 & 0.04 to 0.08 & Moderate \\
\hline & & 2 & 0.08 to 0.12 & High \\
\hline & & 3 & $>0.12$ & Very high \\
\hline \multirow[t]{4}{*}{$\mathrm{C}: \mathrm{N}$} & \multirow[t]{4}{*}{-} & 0 & $<6$ or $>15$ & Not favorable \\
\hline & & 1 & 6 to 8 or 12 to 15 & Moderately favorable \\
\hline & & 2 & 10 to 12 & Too high \\
\hline & & 3 & 8 to 10 & Optimal \\
\hline \multirow[t]{4}{*}{ Organic matter (SOM) } & \multirow[t]{4}{*}{$\mathrm{g} \mathrm{kg}^{-1}$} & 0 & $<10$ & Very low \\
\hline & & 1 & 10 to 40 & Low \\
\hline & & 2 & $>100$ & Too high \\
\hline & & 3 & 40 to 100 & Optimal \\
\hline \multirow[t]{4}{*}{$\mathrm{TN}$} & \multirow[t]{4}{*}{$\mathrm{g} \mathrm{kg}^{-1}$} & 0 & $<2$ & Very low \\
\hline & & 1 & 2 to 10 & Low \\
\hline & & 2 & $>20$ & Too high \\
\hline & & 3 & 10 to 20 & Optimal \\
\hline \multirow[t]{4}{*}{$\mathrm{pH}$} & \multirow[t]{4}{*}{-} & 0 & $<5.5$ or $>8.5$ & Not favorable \\
\hline & & 1 & 5.5 to 6.5 & Risky \\
\hline & & 2 & 7.5 to 8.5 & Moderately favorable \\
\hline & & 3 & 6.5 to 7.5 & Optimal \\
\hline \multirow[t]{4}{*}{ totCaCO${ }_{3}$} & \multirow[t]{4}{*}{$\mathrm{g} \mathrm{kg}^{-1}$} & 0 & $>500$ & Not favorable \\
\hline & & 1 & 250 to 500 & Risky \\
\hline & & 2 & $<10$ or 50 to 250 & Not very favorable \\
\hline & & 3 & 10 to 50 & Optimal \\
\hline
\end{tabular}

3 for optimal quality, 0 for the worst quality based on Vidal-Beaudet et al. (2017) 
2016), (ii) contribution to urban biodiversity (Schrader and Böning 2006), and (iii) increase organic carbon concentration over 4 years (Bouzouidja et al. 2018a).

According to NBS classification described in $\$ 2.1$, the three case studies are classified under the category "forms". However, only the NBSs UAGs and FMGs are classified in the subcategory "on the ground", while GRs are classified in the subcategory "on the building".

\subsubsection{Bustehrad (Czech Republic): green roof NBS}

The experimental site was established on building roofs of the research center facility of the University Centre for Energy Efficient Buildings (UCEEB) in Bustehrad, Czech Republic (N50 09' 24.8" E14 10' 10.8", ground elevation $365 \mathrm{~m}$ a.s.1.) in June 2014 (Jelinkova et al. 2016; Sněhota et al. 2020 submitted to this issue). The site is situated in the brownfield area, characterized by former heavy industry, located $10 \mathrm{~km}$ northwest of the city of Prague and $2 \mathrm{~km}$ of town of Kladno. The climate of the region can be classified as temperate with an average annual rainfall of about $500 \mathrm{~mm}$ and an average annual temperature of 8 ${ }^{\circ} \mathrm{C}$ (Jelinkova et al. 2016). Two experimental plots were set up in 2017 for purpose of long-term monitoring of the GR performance. Each plot has dimensions $1 \times 1 \mathrm{~m}$, with green roof layering representing a typical commercial thin extensive green roof. Two types of growing media were used to develop the extensive green roofs in test beds. The first is a commercially available substrate for extensive green roofs ACRE (Acre, Ltd., Czech Republic) that is composed of crushed spongolite, crushed expanded clay and peat. The thickness of this layer is $5 \mathrm{~cm}$. The second growing medium is a substrate for extensive green roofs BB com (BB com Ltd., Czech Republic) composed of crushed expanded clay, crushed bricks, peat, and compost. The thickness of this layer is around $5 \mathrm{~cm}$. Both plots were planted with a mixture of Sedum spp. cuttings (Sněhota et al. 2019) (Fig. 2a).

\subsubsection{Nancy (France): green roof NBS}

This work was conducted on an in situ experimental platform, built in April 2011, which was set above on a flat roof of a 6-m high building with concrete as a supporting element. The platform is located in Nancy (in the north east of France, under temperate oceanic climate ( $\mathrm{Cfb}$ Köppen-Geiger typology) with a continental trend, $\mathrm{N} 48^{\circ} 41^{\prime} \mathrm{E}^{\circ}{ }^{\circ} 13^{\prime}$ ). The climate on the experimental site is semi oceanic with a continental degraded marked influence, with an average annual precipitation of $763 \mathrm{~mm}$. The average external temperature is $10^{\circ} \mathrm{C}$ with a high amplitude variation between summer and winter (Bouzouidja et al. 2013; Bouzouidja et al. 2018a) (Fig. 2b). The three GR substrates were supplied by Falienor-Terreaux de France and Végétoit (France). They were named according to the composition of each substrate, i.e., "Pine Bark \& Peat" (PBP), "Coco Coir \& Zeolite" (CCZ), and "Compost \& Slag
\& Clay" (CSC). The PBP and CCZ substrates were composed of $80 \%$ pozzolan, and, respectively, $10 \%$ Baltic blond peat and $10 \%$ Pinus pinaster bark for the first one and $0.3 \%$ zeolite and $20 \%$ coco coir for the second one. The CSC was a mixture of recycled terracotta, slags, pozzolan, expanded clay, and compost. The thickness of each substrate layer is $10 \mathrm{~cm}$. All plots were planted with a combination of sedum (Sedum album, Sedum reflexum larix, Sedum reflexum germanium, Sedum sexangulare, and Sedum floriferum). The height of the vegetation is $10 \mathrm{~cm}$.

\subsubsection{Nantes (France): former market gardening and urban allotment garden NBS}

Nantes metropolitan area is the sixth most populous city in France $\left(638,900\right.$ inhabitants in 2019), covering a $534 \mathrm{~km}^{2}$ area

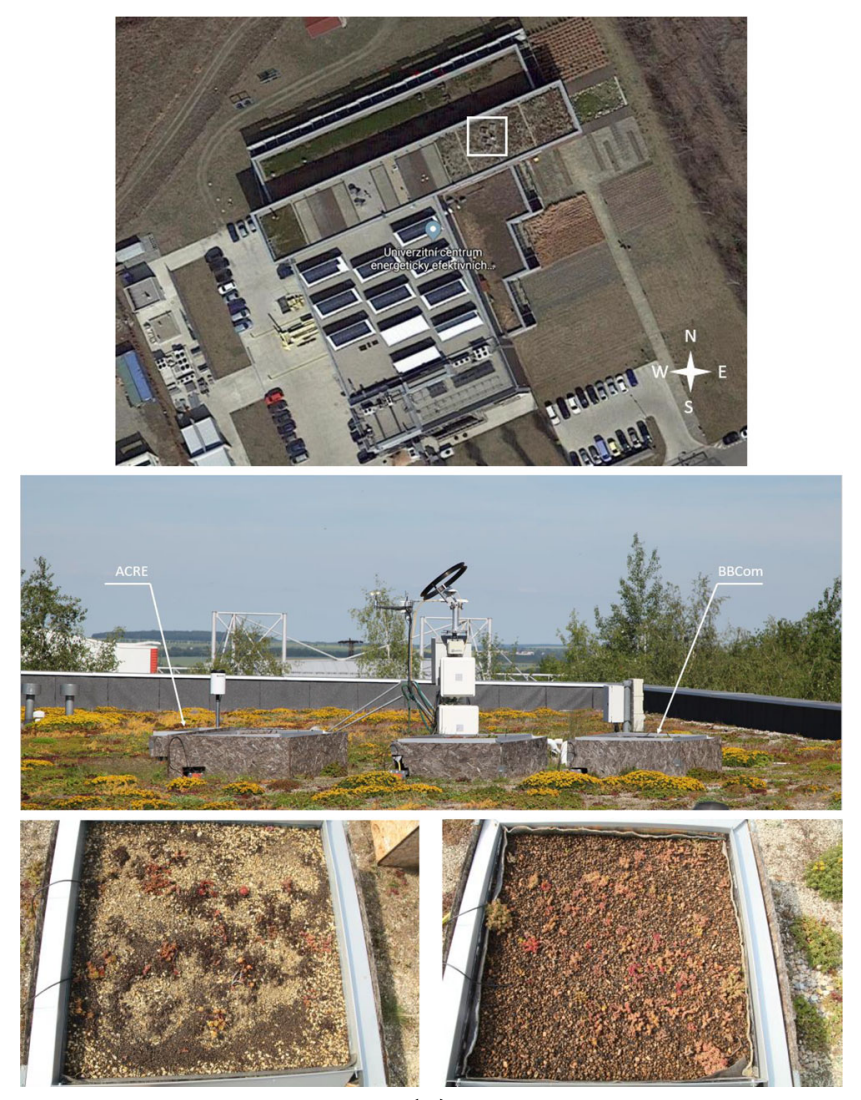

(a)

Fig. 2 a Experimental site at the University Centre for Energy Efficient Buildings in the Czech Republic ; the green roof site positioning at the building's roof with raised beds at the top (Google Maps), the photograph of the raised beds in the middle and top view of the green roof vegetation one year after planting; ACRE bottom left, BB com, bottom right. b Experimental site at the Centre for studies and expertise on risks, environment, mobility, and urban and country planning in France, Nancy; the green roof site positioning at the building's roof with in situ plots at the left (Google Maps), the picture of the plots at the right. c Experimental site at Nantes of Urban Allotment garden (UAG) at the top, the photograph of two UAGs in the middle left and right and a soil profile in the bottom. 

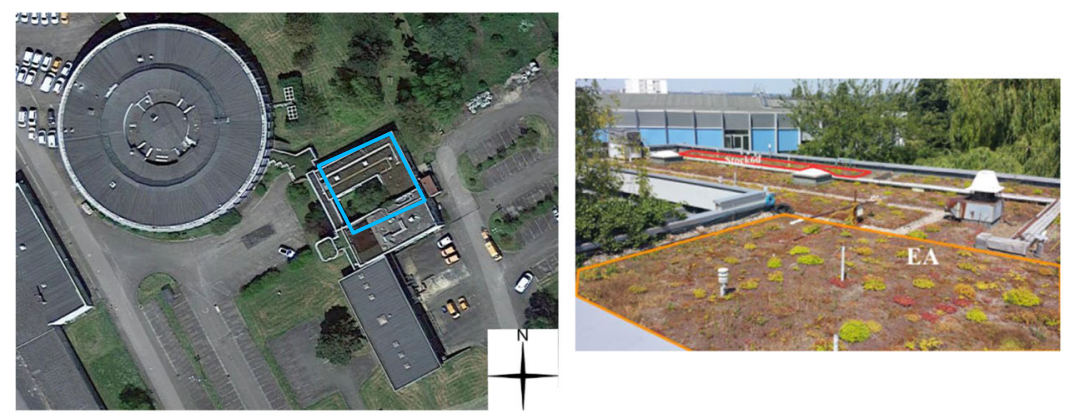

(b)
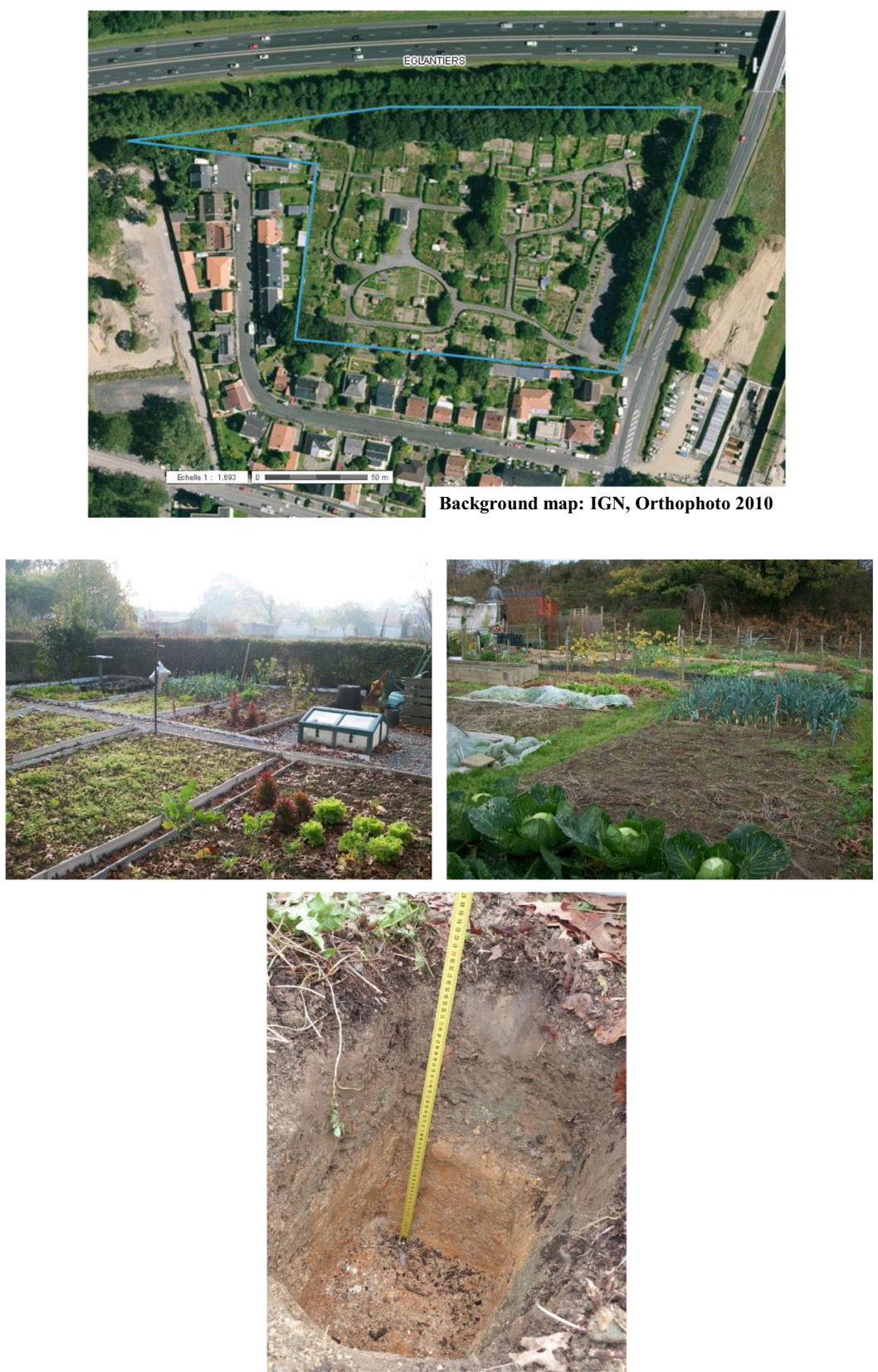

(c)

Fig. 2 (continued) 
and composed of various types of land uses: dense urban in the city center, business and retail zones, suburban zones, and rural zones at the periphery. It is located $40 \mathrm{~km}$ east of the Atlantic Sea coast. The topography is quite flat (from 0 to 90 m). The study sites (Joimel et al. 2016; Béchet et al. 2018; Le Guern et al. 2018) were located at different places around the city on different geological media (e.g., mica schists). The trace element content of soil is influenced by the geochemical background. Some parent materials (in particular mica schists) are source of geogenic arsenic and lead that induce medium to high level of anomalies in soil (Le Guern et al. 2013; JeanSoro et al. 2015; Le Guern et al. 2017; Béchet et al. 2018). The characteristics of the studied UAGs (one example in Fig. 2c of GRs and FMGs) are presented in Table 4.

\subsection{Sampling and laboratory analysis}

The data used in this study came either from the literature or from unpublished data. Three soil datasets were produced from this study. (i) The Bustehrad's dataset is based on an ongoing study introduced by Sněhota et al. (2019) and additional unpublished data, (ii) the Nancy's dataset was initially based on the Schwager et al. (2015) study, (iii) the Nantes' dataset concerning the UAGs is built on previous study conducted by Joimel et al. (2016) and Béchet et al. (2018), and (iv) the Nantes' dataset about FMG is based on an urban renewal project (unpublished data). All these raw data have been postprocessed for the needs of this article. Fourteen plots for UAG were sampled in Nantes ( 5 samples per plot were collected; 0-20-cm depth). Fourteen plots for FMG were sampled (6 to 10 per plot were collected). Three samples were taken from the topsoil $(0-30 \mathrm{~cm})$ layer in each plot. For GR in Nancy (France) and Bustehrad (Czech Republic), three and two replicate samples per setup respectively were picked from the substrate layer. Each sample was collected with roots, preserving the organization of each layer (intact soil cores), and then stored in a container before further lab experiments.
Details of analysis strategy are provided in Table 5. In all cases, ISO 11464 standard was used to prepare soil samples. The samples were dried at a constant temperature and crushed to pass through a 2-mm stainless steel sieve. In the case of the FMG dataset, additional analysis was performed: (i) pesticides because of their intensive use. In 288 molecules (parental molecules and degradation products), (ii) molecular microbial biomass (MMB) was determined according to Dequiedt et al. (2011), with the amount known to be potentially reduced by the use of pesticides (Chowdhury et al. 2008). This analysis is based on the quantification of total DNA extracted directly from the soil sample. The extraction protocol is an optimization of the standard ISO 11063 -extraction protocol from $1 \mathrm{~g}$ of soil, allowing an improvement in the extraction of DNA from fungal communities in particular. Predicted MMB was also determined using Horrigue et al. (2016) model to validate (or not) this model, initially based on a few physicochemical characteristics of crop soils, for market gardening soils.

\subsection{Soil quality interpretation}

We compared the obtained indicators with ideal soil profiles defined for each studied NBS. Indeed, urban soils can be considered as constructed or transformed soils, consisting in a mix of structural or technical layers, which supports a growing soil layer (Fig. 3). Ideal soil profiles consist in soil horizons that promote germination and root development (growing layer), as well as horizons that promote bearing capacity and guarantee the flow of free water (technical layer).

The growing layer should be characterized by (i) a SAW higher than $150 \mathrm{~mm}_{\text {water }} \mathrm{m}_{\text {soil }}{ }^{-1}$, (ii) a drainage capacity higher than $1.4 \times 10^{-5} \mathrm{~m} \mathrm{~s}^{-1}$, and (iii) a high quality rate $(\mathrm{SOM}>40 \mathrm{~g}$ $\mathrm{kg}^{-1}, \mathrm{P}_{2} \mathrm{O}_{5}>0.12 \mathrm{~g} \mathrm{~kg}^{-1}$, and TN between 10 and $20 \mathrm{~g} \mathrm{~kg}^{-1}$ ). The technical layer should be characterized by (i) sufficient SAW (100 to $150 \mathrm{~mm}_{\text {water }} \mathrm{m}_{\text {soil }}{ }^{-1}$ ) and (ii) lower quality $\left(\mathrm{SOM}<40 \mathrm{~g} \mathrm{~kg}^{-1}\right)$. Finally, the structural layer should be characterized by a high bulk density $\left(1.5\right.$ to $\left.1.7 \mathrm{~g} \mathrm{~cm}^{-3}\right)$ and

Table 4 Characteristics of studied nature-based solutions (NBSs) [Urban allotment gardens (UAGs), former market turned into gardening areas (FMGs) and green roofs (GRs)] in the three European cities (Nantes and Nancy in France and Bustehrad in Czech Republic

\begin{tabular}{|c|c|c|c|c|c|c|c|c|c|}
\hline \multirow{4}{*}{$\begin{array}{l}\text { Type of NBSs } \\
\text { No. of plots (-) }\end{array}$} & \multicolumn{7}{|l|}{ France } & \multirow{2}{*}{\multicolumn{2}{|c|}{$\frac{\text { Czech Republic }}{\text { Bustehrad }}$}} \\
\hline & \multicolumn{2}{|l|}{ Nantes } & \multicolumn{5}{|l|}{ Nancy } & & \\
\hline & UAGs & FMGs & GRs & & & & & GRs & \\
\hline & 14 & 14 & 5 & & & & & 2 & \\
\hline Name of studied NBSs (-) & UAG1 to UAG14 & FMG1 to FMG14 & PBP1 & PBP2 & $\mathrm{CCZ}$ & $\mathrm{CSC} 1$ & $\mathrm{CSC} 2$ & ACRE & BB com \\
\hline Surface area of plot $\left(\mathrm{m}^{2}\right)$ (mean) & 100 & 500 & 75 & 20 & 15 & 12 & 18 & 1 & 1 \\
\hline No. of studied samples (in lab) (-) & 5 & 6 to 10 & 3 & 3 & 3 & 3 & 3 & 2 & 2 \\
\hline
\end{tabular}

PBP means Pine Bark and Peat, CCZ means Coco Coir and Zeolite and CSC means Compost and Slag \& Clay. 
Table 5 Soil samples collected method of sampling and analysis of physical, chemical and biological properties used for each city

\begin{tabular}{|c|c|c|c|c|c|}
\hline \multirow[t]{2}{*}{ Parameter } & \multicolumn{3}{|c|}{$\begin{array}{l}\text { Nature-based } \\
\text { solutions - NBSs } \\
\text { type }\end{array}$} & \multirow[t]{2}{*}{ Method used } & \multirow[t]{2}{*}{ References } \\
\hline & FMG & UAG & GR & & \\
\hline \multicolumn{6}{|l|}{ Physical parameters } \\
\hline Soil texture & $\mathrm{X}$ & $\mathrm{X}$ & $\mathrm{X}$ & Soil textural triangle ${ }^{*,+,+, \neq}$ & (Minzenmayer 1979) \\
\hline $\mathrm{D}_{\mathrm{b}}$ & $\mathrm{X}$ & $\mathrm{X}$ & - & Pedotransfer function ${ }^{*},+, \neq$ & (Cambou et al. 2018) \\
\hline SAW & $\mathrm{X}$ & $\mathrm{X}$ & $\mathrm{X}$ & Linear regression of Rawls ${ }^{*},+, \neq$ & $\begin{array}{l}\text { (Rawles and Brakensiek 1982; Rawles } \\
\text { et al. 1991) }\end{array}$ \\
\hline \multicolumn{6}{|l|}{ Chemical parameters } \\
\hline SOM & $\mathrm{X}$ & $\mathrm{X}$ & $\mathrm{X}$ & - & (ISO 10694, 1995; ISO 13878 1998) \\
\hline $\mathrm{TN}$ & $\mathrm{X}$ & $\mathrm{X}$ & $\mathrm{X}$ & - & (ISO 10694 1995; ISO 13878, 1998) \\
\hline totC & $\mathrm{X}$ & $\mathrm{X}$ & $\mathrm{X}$ & - & \\
\hline totCaCO $\mathrm{Ca}_{3}$ & $\mathrm{X}$ & $\mathrm{X}$ & $\mathrm{X}$ & - & (ISO 10693, 1999) \\
\hline $\mathrm{C}: \mathrm{N}$ & $\mathrm{X}$ & $\mathrm{X}$ & $\mathrm{X}$ & Dividing totC by $\mathrm{TN}^{*},+, \neq$ & - \\
\hline $\mathrm{P}_{2} \mathrm{O}_{5}$ & $\mathrm{X}$ & $\mathrm{X}$ & $\mathrm{X}$ & Olsen's method & (ISO 11263, 1995) \\
\hline $\mathrm{pH}_{\text {water }}$ & $\mathrm{X}$ & $\mathrm{X}$ & $\mathrm{X}$ & $\mathrm{pH}$ meter ${ }^{*},+, \neq$ & (ISO 10390, 2005) \\
\hline CEC & $\mathrm{X}$ & $\mathrm{X}$ & $\mathrm{X}$ & Ammonium acetate method ${ }^{*},+, \neq$ & (Kahr and Madsen 1995) \\
\hline Pesticides & $\mathrm{X}$ & & & & (AFNOR 2003) \\
\hline \multicolumn{6}{|l|}{ Biological parameters } \\
\hline MMB & $\mathrm{X}$ & & & - & (Dequiedt et al. 2011) \\
\hline \multicolumn{6}{|l|}{ TEs } \\
\hline $\begin{array}{l}\mathrm{Cd}, \mathrm{Cr}, \mathrm{Cu}, \mathrm{Ni}, \mathrm{Pb} \\
\text { and } \mathrm{Zn}\end{array}$ & $\mathrm{X}$ & $\mathrm{X}$ & $\mathrm{X}$ & $\begin{array}{l}\text { AAS (atomic absorption spectrometry) with flame and } \\
\text { electrothermal atomization }{ }^{*} \text {. } \\
\text { ICP-OES/MS and PXRF in laboratory and in situ } \\
\text { ICP-AES }{ }^{*}+\end{array}$ & (Danielsson et al. 1978) \\
\hline
\end{tabular}

${ }^{*}$ means that methods were made for Nantes, ${ }^{+}$for Nancy and ${ }^{\ddagger}$ for Bustehrad. ${ }^{¥}$ the texture represents the mineral fraction

does not need to be fertile or to provide SAW. Ideal soil profiles are defined for each expected NBS. To go further, the study of trace elements has been done. The metal contents of the case studies were compared with local conditions: (i) average local geochemical background for FMGs and UAGs and (ii) mandatory standard for growth media for GRs. Finally, molecular microbial biomass indicator is used in order to identify the level of perturbation of the studied areas.

\section{Results and discussion}

\subsection{Specific soil quality according to the type of NBS based on the simplified quality assessment method}

The overall soil properties for the studied NBS, i.e., FMG, UAG, and GR, are illustrated in Fig. 4 (and suppl. data Table S1). All of NBSs have relatively close textures ranging from sandy loam to silty sand (GRs and FMGs) to silty sand (UAGs) according to the soil texture triangle classification (results not shown). Overall, the mean $\mathrm{pH}$ was alkaline in all three NBSs, with low variability, ranging from 6.5 to 8.1. This alkalinity is probably due to a relatively high supply of organic matter (38.6 to $\left.70.0 \mathrm{~g} \mathrm{~kg}^{-1}\right)$ and totCaCO $3\left(2.6\right.$ to $\left.6.2 \mathrm{~g} \mathrm{~kg}^{-1}\right)$. The addition of organic matter results in an increase in CEC, carbonates and/or metal oxides. The mean values of SOM in the FMGs and GRs were significantly higher $(48.7 \pm 20.3$ and $70.0 \pm 13.4 \mathrm{~g} \mathrm{~kg}^{-1}$, respectively) than SOM in the reference soils in France (forest soils) $\left(40 \mathrm{~g} \mathrm{~kg}^{-1}\right)$ (Joimel et al. 2016). Its value remains below $40 \mathrm{~g} \mathrm{~kg}^{-1}$ for UAGs $\left(34.3 \pm 13.4 \mathrm{~g} \mathrm{~kg}^{-1}\right)$. In the review of Liu et al. (2019), the authors found that the SOM value of forest varied from $20.1 \pm 5.8$ in Germany to $32.5 \pm 17.0 \mathrm{~g} \mathrm{~kg}^{-1}$ in Spain. Concerning physical properties, all three sites, the soils had a relatively high SAW (mean and median of $151 \mathrm{~mm}_{\text {water }} \mathrm{m}_{\text {soil }}{ }^{-1}$ and $154 \mathrm{~mm}_{\text {water }} \mathrm{m}_{\text {soil }}{ }^{-1}$, respectively); which is corresponding to a score of 3 and considered as moderate according to the recommendations for growing soils (Table 2). The highest levels were in Bustehrad in ACRE substrate $\left(190.6 \mathrm{~mm}_{\text {water }} \mathrm{m}_{\text {soil }}{ }^{-1}\right)$ because of high internal porosity of spongolite stone, and the lowest in UAGs (135.2 $\pm 11.0 \mathrm{~mm}_{\text {water }} \mathrm{m}_{\text {soil }}{ }^{-1}$ ) (suppl. data Table $\mathrm{S} 1$ ). In addition, the same is observed for the bulk density $\left(D_{b}\right)$ 
Fig. 3 Representation of the soil horizons a reference values of the physical and chemical indicators (bulk density $\left[\mathrm{D}_{\mathrm{b}}\right]$, soil available water for plants [SAW], soil organic matter [SOM], total nitrogen $[\mathrm{TN}], \mathrm{C}: \mathrm{N}$ ratio $[\mathrm{C}: \mathrm{N}]$, Phosphorus $\left[\mathrm{P}_{2} \mathrm{O}_{5}\right]$, cation exchange capacity [CEC], total carbonates $[$ totCaCO 3 ], and soil $\mathrm{pH})$ for NBSs (growth layer); b sketch of the arrangement of the growth layer adapted from VidalBeaudet et al. (2017) (a)

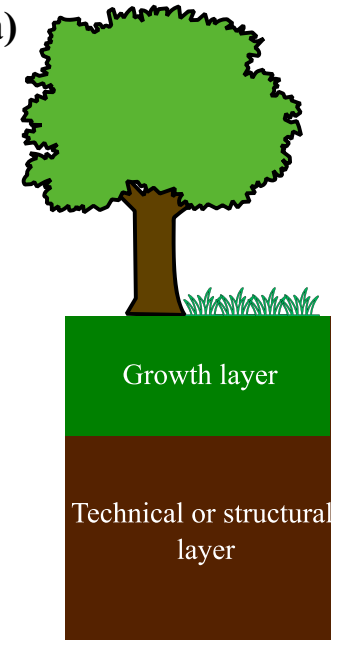

(b)

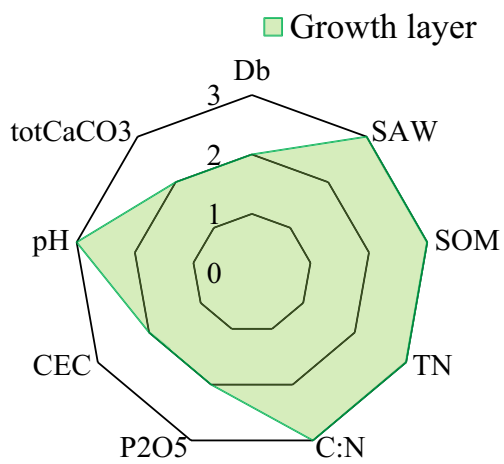

(score of 3, less than $1.2 \mathrm{~g} \mathrm{~cm}^{-3}$ ) (Fig. 4). All three NBSs had rather low totCaCO 3 values (score of 2, content ranging from 50 to $250 \mathrm{~g} \mathrm{~kg}^{-1}$ depending on the NBS) (Table S1 and Fig. 4 ), and the organic carbon content was probably overestimated when totCaCO 3 was concentrated. High $\mathrm{P}_{2} \mathrm{O}_{5}$ contents (score of 3) ranging from 0.2 to $1.0 \mathrm{~g} \mathrm{~kg}^{-1}$ were observed in Nantes (FMG and UAG) and Bustehrad (GRs). Contrasted values of CEC were found between NBSs: high values in Bustehrad (GRs) $\left(28.1 \pm 2.0\right.$ meq $\left.100 \mathrm{~g}^{-1}\right)$ and low values in Nantes (FMGs and UAGs) and Nancy (GRs) (6.2 \pm 2.1, $8.0 \pm 1.7$ and $8.1 \pm 0.8$ meq $100 \mathrm{~g}^{-1}$ respectively).

The metal contents in soils of UAG, FMG, and GR are summarized in Fig. 5 (and suppl. data Table S2). The soil samples collected in Nantes (Fig. 4a: UAGs and FMGs) contain higher concentrations of trace elements (TE) than substrates making GR (Fig. 5b). The TE values recorded for UAG and FMG $(\mathrm{Cu}, \mathrm{Pb})$ are higher than the local geochemical background (Le Guern et al. 2013; Le Guern et al. 2017), except Ni, as already shown by Béchet et al. (2018) and Joimel et al. (2016) for $\mathrm{Cu}$ and $\mathrm{Pb}$ in UAGs. Specifically, $\mathrm{Cu}$ exceeds the geochemical background by a factor of 3.4, most probably as a result of the historic use of copper sulfate (Bordeaux mixture) as a fungicide. Average concentrations in $\mathrm{Cu}\left(47.4 \mathrm{mg} \mathrm{kg}^{-1}\right)$ are similar for UAG and FMG (47.5 mg kg${ }^{-1}$ ) while concentrations of $\mathrm{Pb}$ are slightly higher $(11.3 \%)$ in FMG $\left(68.4 \pm 19.1 \mathrm{mg} \mathrm{kg}^{-1}\right)$ as compared with UAG $\left(56.9 \pm 35.5 \mathrm{mg} \mathrm{kg}^{-1}\right)$. $\mathrm{Pb}$ may derive from fungicides (a)

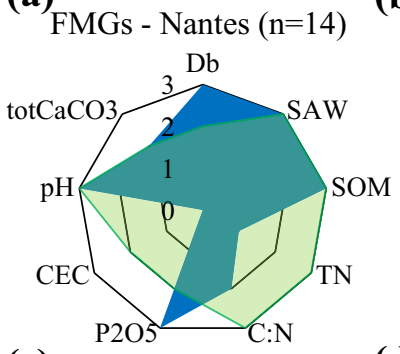

(c)

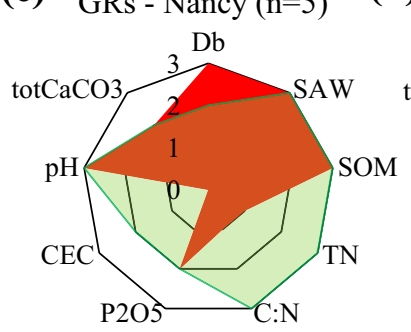

Fig. 4 Compared reference values (clear green area) and mean values for the physical and chemical indicators for the three NBS observed at a Nantes for the FMGs (blue area), b Nantes for the UAGs (yellow area), c Nancy for GRs (red area), and d Bustehrad for GRs (grey area). tot $\mathrm{CaCO}_{3}$ is the total calcium carbonate content. SOM is the soil

d) (b) UAGs - Nantes ( $\mathrm{n}=14)$
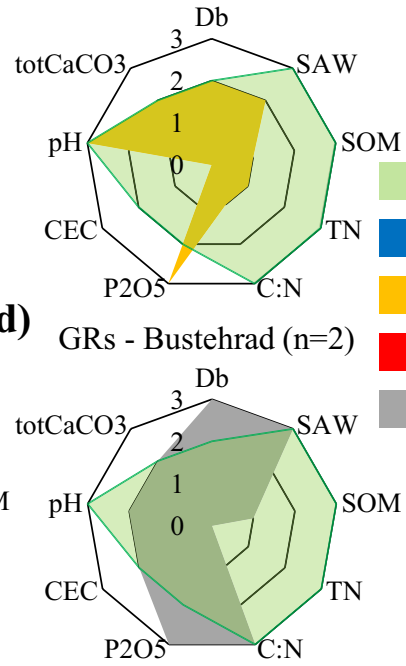

organic matter. $C E C$ is the cation exchange capacity. $T N$ is total nitrogen. $\mathrm{C}: \mathrm{N}$ ratio is the carbon-to-nitrogen ratio. $\mathrm{P}_{2} \mathrm{O}_{5}$ is available phosphorus. SAW is the soil available water. $D_{b}$ is the bulk density. $n$ is the number of plots per city 
(a)

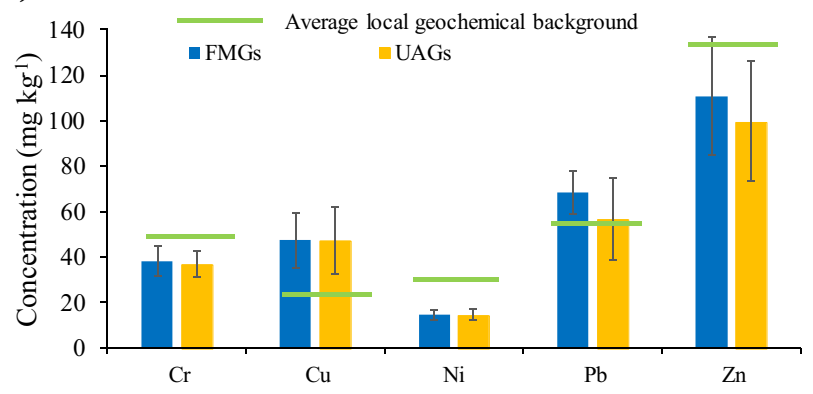

(b)

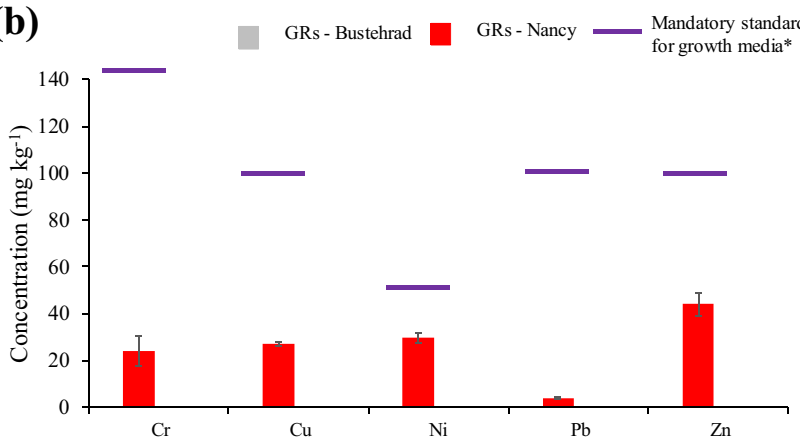

Fig. 5 Bars plots of trace element concentrations $(\mathrm{Cr}, \mathrm{Cu}, \mathrm{Cr}, \mathrm{Ni}, \mathrm{Pb}$, and $\mathrm{Zn}$ ) in a urban allotment garden and former market gardens surface soils of Nantes (France) (green lines are the local geochemical background according to Le Guern et al. (2017) and $\mathbf{b}$ green roofs in Nancy. Purple continuous line represents the mandatory standard for growth media Designations, specifications, marking - Supports de culture (*) (AFNOR 2009)

widely used in marked gardening (banned for many years) that probably explain why FMG soils are enriched in these TE (Defoe et al. 2014).

TE concentrations in Nancy (GRs) by far exceeded TE concentrations in Bustehrad (suppl. data Table S2). This is could be due to higher atmospheric deposits (Jelinkova et al. 2016). Douay et al. (2008) exhibited that in France, $\mathrm{Cu}$ and $\mathrm{Zn}$ levels in soils are significantly impacted by atmospheric deposits. Up to now, there are no standards or regulations that mention thresholds for TE concentrations to be respected for soils or substrates used in GR. These values are considered ordinary, with a moderate to strong anomaly compared with the reference data on French agricultural soils (Baize 1994). The maximum levels of the NF U44-551 (AFNOR 2009) standard for growing media have also been indicated in Fig. $5 \mathrm{~b}$. In the Nancy site, the mean TE concentrations did not exceed the threshold authorized for the growth media as well as the natural anomaly threshold except for the $\mathrm{Cu}(26.9 \pm$ $1.8 \mathrm{mg} \mathrm{kg}^{-1}$ ). Possible overrunning of these thresholds related to growing media underline the need to analyze the substrates, as roof-mounted vegetable crops gradually develop (Aubry 2013; Aubry and Kebir 2013). The level of $\mathrm{Cu}$ in the Nancy GRs substrate could derive from its composition, which includes recycled materials such as crushed brick or coal slag (Beecham and Razzaghmanesh 2015).

\subsection{Accuracy of the simplified quality assessment method vs soil quality for sustainable NBS}

Simplified fertility assessment for evaluating urban soil quality is interesting because it is straightforward to implement, but it also has limitations. In fact, urban soils are strongly influenced by natural and anthropic factors (e.g., fertilizer application, vehicular emissions, industrial wastes, wastewater sludge, anthropic materials...). According to that, urban soils may be fertile but may also have some contamination (e.g., heavy metal) (Schwartz et al. 2000). The origin of the urban soils, their physicochemical compositions, and their mineralization contents may sometimes be due to anthropogenic factors, especially in urban areas (Pateraki et al. 2019). In addition, the studied NBS soils can be considered as an efficient urban garden and brownfield lands in the case of UAGs and FMGs (Hartley et al. 2009; Edmondson et al. 2014) and anthropized soils named Technosols in the case of GRs (IUSS Working Group WRB 2015; Bouzouidja et al. 2018a). The tested NBS displayed different fertility, high physical properties (e.g., bulk density from 0.7 to $1.2 \mathrm{~g}$ $\mathrm{cm}^{-3}$ ), low chemical properties for UAGs and FMGs (e.g., CEC from 6.2 to 8.0 meq $100 \mathrm{~g}^{-1}$ ), whereas they are higher in the case of GR ( 8.1 to 28 meq $100 \mathrm{~g}^{-1}$ ); while totCaCO 3 is considered not very favorable (from 2.6 to $6.1 \mathrm{~g} \mathrm{~kg}^{-1}$ ) for all NBSs. These values can be related to the activities and intensity of management of these soils. Calcium carbonate is important in soils. Calcium plays a structuring role in the soil thanks to the cationic bridge it provides within the clay-humic complex. It is also an important element for plant growth and health. The carbonate as for place allows of contributing to the improvement of the $\mathrm{pH}$ of the soil. For example, Voigt et al. (2015) studied the soil management practices (cultivation) of allotment gardens in Lisbon, Portugal. They observed that the chemical contents (case of tot $\mathrm{CaCO}_{3}$ ) were more important $\left(40.9 \pm 8.6 \mathrm{~g} \mathrm{~kg}^{-1}\right)$ compared to the French UAGs $(4.2 \pm$ $5.9 \mathrm{~g} \mathrm{~kg}^{-1}$ ) with more homogeneous soil management. In the case of GR (Nancy and Bustehrad), low carbonate concentration ( 4.7 to $6.1 \mathrm{~g} \mathrm{~kg}^{-1}$ ) is not due to the practice of the study site (nil in both cases) but rather to the hydrodynamic conditions. Indeed, the alternation of wet/dry cycles may have favored carbonate leaching due to the stabilization of sorbed ions (Han et al. 2001). In terms of TE contamination, UAG and FMG appear to be the most contaminated mainly by lead ( 56.9 to $68.4 \mathrm{mg} \mathrm{kg}^{-1}$ ). It is also higher than the geochemical background values ( $46 \mathrm{mg} \mathrm{kg}^{-1}$ ) (Le Guern et al. 2017). This method allowed us to highlight the heterogeneous behavior of urban soils (constructed soils in the case of GR and existing soils in the case of UAGs and FMGs) of NBS. Nevertheless, at this stage, we cannot yet decide on the relevance of using only soil fertility and contamination to determine the quality of soils and thus the performance of NBSs. We need feedback on more case studies (e.g., biological activity). 


\subsection{Relevance of biological indicators to improve the simplified soil quality assessment method}

Physical and chemical characteristics of soils are not sufficient to estimate their biological quality. And when models are able to predict, e.g., the molecular microbial biomass (MMB) (model developed by Horrigue et al. (2016)), based on a few physicochemical characteristics of crop soils, one might wonder about the accuracy of models for market gardening soils. This is the reason why several biological indicators have been developed in natural and cropped soils (e.g., bioindicators of the soil state, from ADEME, France). Among them, the molecular microbial biomass is easily and quickly accessible and could be included in the simplified soil quality assessment. In FMG, some pesticides were quantified: transchlordane, $\mathrm{p}, \mathrm{p}^{\prime}-$ DDE, dieldrin, dimethomorph, diuron, heptachlor epoxide cis, hexachlorobenzene (HCB), norflurazon, pendimethalin, pentachloroaniline, pentachlorophenyl vinyl sulfide, quintozene, and trifluralin. In this context where pesticides were used in large amounts - pesticides cost in France reached $685 € /$ ha in 2002 (vegetable growing) as compared with $287 € /$ ha for vine growing and $121 € /$ ha for cereals and oil seeds crops (Aubertot et al. 2005) - the quality of soils is supposed to be impaired, especially the microbial component. MMB (total amount of DNA extracted from the soil) is negatively correlated to the sum of the pesticides' concentrations measured in each plot-13 parental molecules and degradation products pesticides out of 288 which were searched out (data not shown). It is noteworthy that MMB values for our 14 FMG plots are below the predictive values based on a collection of crop soils (Horrigue et al. 2016). For 3 of them (FMG1, FMG2, and FMG5), they are between 70 and $90 \%$ of the predictive value (Fig. 6a), which corresponds to an altered but noncritical level whereas for the other plots, the values are below 70\%, which corresponds to highly altered MMB values. The discrepancies between the predictive and the measured values (observed to modelled MMB ratio) are even higher as pesticides concentrations are high (Fig. 6b), which reduces the robustness of this predictive model, which was originally developed in crop context. On can conclude that in the case of contaminated soils which is a common situation in urban context with, e.g., trace element concentrations being higher than in agricultural soils (Wei et al. 2008), the use of biological indicators is essential to accurately describe the whole quality of soils and their ability to support NBS. In a community garden in Nantes, where $\mathrm{Pb}$ concentration was 2.5-times higher than background levels and considered as moderate anomaly, $\mathrm{Pb}$ modified fungi communities and altered the functional structure of collembolan communities (Joimel et al. 2018). Yet, soil biological communities play a significant contribution to the soil fertility, and any perturbation can seriously affect biogeochemical cycles. Eventually, in the predictive model proposed by Horrigue et al. (2016), the concentration of contaminants such as pesticides must be incorporated in the model to avoid any overestimation of MMB.

\subsection{Simplified methodology to assess NBS performances}

Nature is once again being reintroduced into the cities. It takes on different forms. As a result, urban planning has to take into account new challenges in order to develop and implement urban development or renewal projects. Therefore, the implementation of a new NBS requires an examination of the developed area (e.g., soil quality, local plants use). It is crucial to carefully pave the way for a new investment with caution. By taking into account soil management challenge and integrating it with other challenges (e.g., climate mitigation, water management) within the $\mathrm{N} 4 \mathrm{C}$ project, this project aims to give a general picture of the expected benefits of an NBS implementation. The adaptation of cities to societal challenges (e.g., climate, environment) requires the integration of soil as a decision-making element in the planning of urban areas (Gaston et al. 2013). As we already have seen, our methodology represents relevant suggestions for municipalities because it helps to match land use and soil quality (Vrščaj et al. 2008).

Because the soil is the main component of the urban environment, an operational scheme is proposed to help when the selection of NBSs needs a soil quality assessment. The methodology developed to take into account soil quality is presented in Fig.7. It aims to take into account soil properties (physical, chemical, and biological) and anthropogenic conditions
Fig. 6 Molecular microbial biomass (MMB) in FMG soils a representation of spider diagram MMB threshold (dotted orange line) and measured MMB (dotted red line) and $\mathbf{b}$ observed to modelled MMB ratio $\left(\mathrm{MMB}_{\mathrm{obs}}\right.$ ' $\mathrm{MMB}_{\text {mod }}$ ) in relation to the sum of pesticides (a)

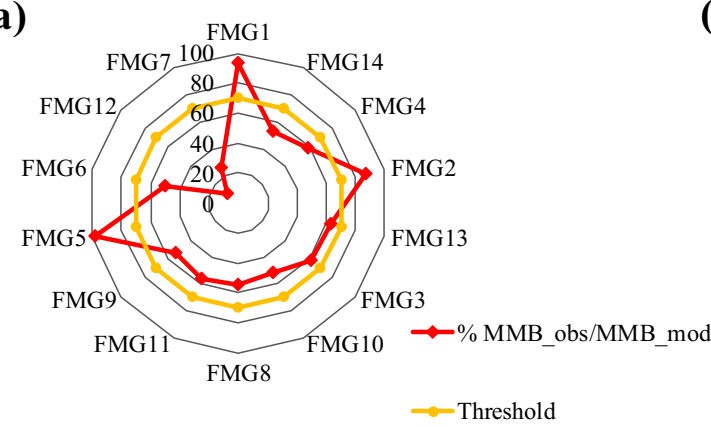

(b)

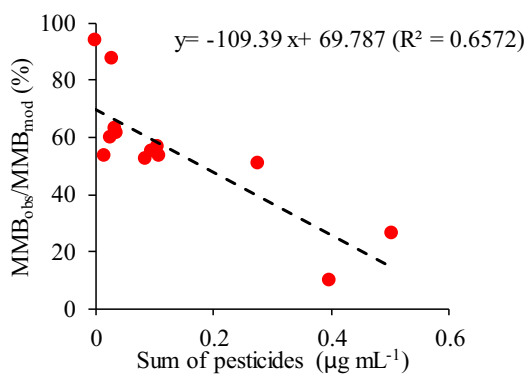




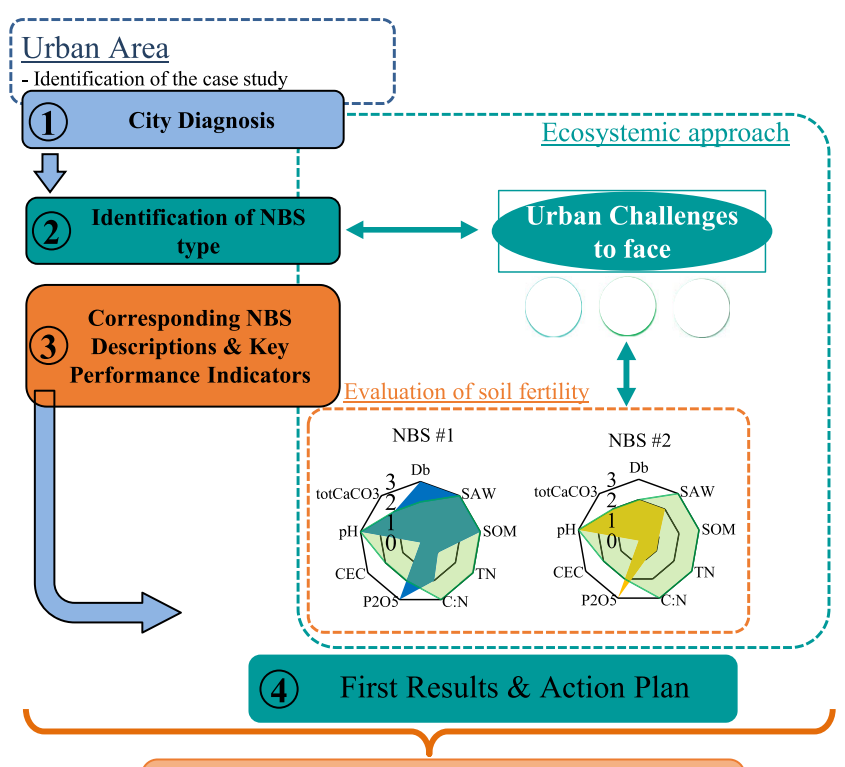

(5) Global analysis of case studies regarding the urban soil quality

Fig. 7 Methodology of the simplified decision-support tool applied to NBS used in the Nature4Citites (N4C) project (Nature4Cities 2016) contribution of soil fertility on urban soil quality to respond to urban issues. The two NBSs (yellow and blue surface) are compared with the baseline data (green surface)

(e.g., fertilizer application, pesticides). The first phase is to identify the case study, for example, "Nancy GR project" based on a comprehensive overview of all existing data. Afterwards, the categorization of the type of NBS from Nature4Cities project is used (on the ground/related to water/on buildings or structures/strategies/actions) in relation to urban challenges. In this case, GR is considered as NBS "On the buildings or structures" with a positive impact on water management and biodiversity and a cobenefit on urban climate regulation. The subsequent phase consists of matching the NBSs, through the challenges it addresses, with key performance indicators (e.g., soil fertility). These are weighted according to their relevance to each soil property in an equivalent manner (no weighting was given to the indicators). The three compartments (biological, chemical, and physical aspects) are interconnected. The final phase of the analysis of the results (soil quality) begins once the urban soil properties (biophysicochemical) have been characterized. For example, both NBSs \#1 and \#2 have one of the weak chemical properties (e.g., CEC). Suggestions to improve chemical fertility would be organic inputs, nondisruption of the system, which promotes biological activity. Our results confirm that the quality of urban soils should take into account all processes (biological, physical, and chemical) for a better estimation of soil performance in the presence of NBS as described by Blanchart et al. (2018). To illustrate, Doick et al. (2009) showed in the context of FMG that the environmental impacts are essential to the success of a development and rehabilitation project.
Adhikari and Hartemink (2016) showed in their review that it was not conceivable to install an in-ground garden on contaminated soil.

\subsection{Limitation of the simplified methodology}

An important limitation of the simplified approach is the difficulty of jointly taking into account the different challenges that NBSs can tackle but also the interactions between the compartments of the ecosystem (water, atmosphere, soil). Urban soils, as natural and man-made resources, contribute significantly to fundamental ecosystem services for sustainability (e.g., air quality, water management, climate regulation, food production) (Pereira et al. 2018). A large number of studies on the relationship between urban soils and soil services (e.g., provisioning, regulation) have been carried out in the last decades (among others, Craul 1992; Morel et al. 2005; Kumar and Hundal 2016; Joimel et al. 2016; Levin et al. 2017). Several frameworks for the valuation of soil ecosystem services have been developed (Hewitt et al. 2015). However, we have identified that our case studies were very limited compared with other challenges such as climate regulation and water management except for the green roofs. For example, Blanchart et al. (2018) argued that carbon sequestration by plants and soil has a major influence on climate regulation through greenhouse gases. In our study, the SOM indicator only deals with soil quality.

On the other hand, a streamlining process to group NBS with similar impacts on urban challenges, as introduced in the N4C methodology, allows to precisely target the priority challenge for certain NBSs. Thus, the UAGs and FMGs have a moderate contribution to urban storm water runoff quality regulation (Bell et al. 2007). Nevertheless, in the case of GR, this NBS can absorb rainwater (Simmons et al. 2008) and therefore reduce storm water runoff and combined sewage overflows (Mentens et al. 2006). This observation can also be extended more broadly to the consideration of the economic component in the development of NBSs. Population increase is a significant exogenous pressure on three main sources: water, energy, and food (WEF) nexus (Mohtar and Lawford 2016). With increasing populations, there is a need to increase food production in order to meet the growing demand for food. Global food and nutrition security are strongly influenced by the quality of the soil and the environment. The qualities of soils, plants, animals, and people are closely linked (Lal 2009). Urban soil functions can be the result of significant climatic factors, the nature of the soil or human impact (Rawlins et al. 2015). Therefore, soil quality improvement should also take into account the effects of socioeconomic (e.g., economic stability, social equity) and biophysical (e.g., climate, urban land management) factors (Lal 2016).

Furthermore, soil quality assessment tools and methods are based on a large number of indicators or complex assessment 
procedures that are difficult to set up and understand by the actors involved in planning (Blanchart et al. 2018). Within the $\mathrm{N} 4 \mathrm{C}$ project, all data collection campaigns are globally carried out in collaboration with the municipalities and technical partners involved. In some cases, data collection has followed a linear process, and in other cases, where the data to be collected is more problematic, there has been an iterative process to overcome weaknesses in which potential data requirements are made.

Urban soils are considered differently depending on the community. For example, the soil science community views urban soils as a man-made mixture of materials differing from agricultural or forest ones (Craul 1992) and capable of providing ecosystem services (Morel et al. 2015). From NBS community perspective, urban soils are described as a delineated surface area fulfilling a regulatory role (e.g., carbon sequestration) (Dicks et al. 2017; Raymond et al. 2017; Watt et al. 2019). Based on this background, it is evident that the indicators of this soil quality are not similar.

Urban soils are globally the site of major modifications (e.g., compaction, exogenous soils). For example, compaction modifies the structure of these soils (Gregory et al. 2006; Cannavo et al. 2014). Anthropogenic urban soils (case of unsealed soils) are most often characterized by a rapid evolutionary pattern that can be explained by an imbalance with their environment (Séré et al. 2012). This implies that their physicochemical properties are likely to evolve rapidly. This has been found on some NBSs, such as GRs (Bouzouidja et al. 2018a). In the case of our study and more generally of the $\mathrm{N} 4 \mathrm{C}$ project, we did not take into account the evolution of properties over time due to the complexity of the interaction with other challenges (e.g., climate regulation, urban planning).

Finally, soil quality indicators were tested here on a selection of certain NBS in a few pedoclimatic zones. These nonexhaustive choices deserve to be completed by other situations. Nevertheless, their wide range of climatic conditions, geology, population density, and sources of pollution give a fairly good representation of the possible fields of action.

\section{Conclusion}

Urban areas are home to major local environmental concerns such as food sufficiency, flood mitigation, urban heat island, and soil. In this context, soil issues and soil preservation can therefore be considered as a major issue. Some strategies for improving soil quality have been made. Nevertheless, it can be observed that urban soils are often neglected or just treated succinctly (only the first $30 \mathrm{~cm}$ ). Managers and planners have very little interest in the subsoil and in particular the biological, physical, and chemical property aspects. It is important to include the quality of urban soils in urban planning. We discussed the fact that urban soils, as a support for nature, are one of the main providers of fundamental ecosystem services (e.g., air quality, flood mitigation, food production, climate adaptation). We have identified the key indicators that should be taken into account to develop a simplified decision support tool to improve the quality of urban soils in the presence of nature-based solutions (NBS) for urban planning projects and, consequently, to optimize the ecosystem services provided by urban soils. In addition to physicochemical parameters to assess fertility and contaminant retention, biological parameters are necessary for a more accurate soil quality assessment. With current techniques (molecular biomass in particular), these indicators become as simple and inexpensive to obtain as the physicochemical characteristics of the soil. The N4C work on soil quality has made it possible to develop specific soil indicators, which will soon be aggregated with all the indicators proposed in the project, to respond to the various urban challenges. The urban stakeholders will have a decision-support tool on which to base the definition of the most appropriate NBS for their development projects. There is, however, a risk associated with limiting the number of indicators. For example, the UPIs proposed in N4C do not include indicators of direct contamination, as the choice was made to include more encompassing indicators such as effect on biodiversity. As a result, the data to be acquired may be more complex to interpret. A case-by-case approach, with operational expert advice, particularly on the "initial diagnosis" phase when selecting NBSs, would certainly be more relevant. We studied the soil properties of NBSs located and used in three different cities in Europe: Bustehrad in Czech Republic, Nantes, and Nancy in France. Understanding urban soil quality was noticed, using soil fertility (physical, chemical, and biological parameters) as inputs. Urban soil quality assessment in the former market gardening areas (FMG), urban allotment gardens (UAG), and green roofs (GR) produced different results. In the case of physical properties, the soil characteristics of the FMG and GR were close to the reference values due to suitable maintenance conditions.

Acknowledgments The authors would like to thank Samuel DEQUIEDT for his implication and his microbial molecular biomass model. Finally, all the authors would like to thank the anonymous reviewers for their comments and suggestions, which helped to improve the quality of the manuscript.

Funding information This work was supported by the European Union program SCC-03-2016: New governance, business, financing models, and economic impact assessment tools for sustainable cities with nature-based solutions (urban renaturing) (grant number 730468) under the research project Nature4Cities (N4C) - "Nature Based Solutions for renaturing cities: knowledge diffusion and decision support platform through new collaborative models", the Czech Republic funding (Ministry of Education, Youth and Sports within National Sustainability Programme, project number LO1605 and with financial support from the 
Czech Science Foundation under project number 17-21011S). This work is also part of the TERRACES research project (ImpacT of vEgetative Roofs on uRban Ambiances: Cooling effects, Environment and Spreading), which are funded by the French Environmental Agency, ADEME and the French National Research Agency (JASSUR project ANR-12-VBDU-0011). This work was also financed by France's Pays de la Loire Regional Council (under the POLLUSOLS-OSUNA Project).

\section{Compliance with ethical standards}

Research involving human participants and/or animals This article does not contain any studies involving animals and human participants performed by any of the authors.

No informed consent needed for this study.

Conflict of interest The authors declare that they have no conflict of interest.

Open Access This article is licensed under a Creative Commons Attribution 4.0 International License, which permits use, sharing, adaptation, distribution and reproduction in any medium or format, as long as you give appropriate credit to the original author(s) and the source, provide a link to the Creative Commons licence, and indicate if changes were made. The images or other third party material in this article are included in the article's Creative Commons licence, unless indicated otherwise in a credit line to the material. If material is not included in the article's Creative Commons licence and your intended use is not permitted by statutory regulation or exceeds the permitted use, you will need to obtain permission directly from the copyright holder. To view a copy of this licence, visit http://creativecommons.org/licenses/by/4.0/.

\section{References}

Adhikari K, Hartemink AE (2016) Linking soils to ecosystem services a global review. Geoderma 262:101-111. https://doi.org/10.1016/j. geoderma.2015.08.009

AFNOR (2003) Soil quality - Determination of organochlorine pesticides and polychlorinated biphenyls - Gas-chromatographic method with electron capture detection - Qualité du sol

AFNOR (2009) NF U44-551/A4 December 2009-Growing media - designations, specifications, marking - Supports de culture

Alberti M (2017) Grand Challenges in Urban Science. Front Built Environ 3. https://doi.org/10.3389/fbuil.2017.00006

Arora S, Arora S, Sahni D, Sehgal M, Srivastava D, Singh A (2019) Pesticides use and its effect on soil bacteria and fungal populations, microbial biomass carbon and enzymatic activity. Curr Sci 116: 643-649

Aubertot JN, Barbier JM, Carpentier A, Gril JJ, Guichard LL, Lucas P, Savary S, Savini I, Voltz M, Bonicelli B, Ruelle P, Laplana R, Turpin N (2005) Inra-Cemagref collective expertise: reduction of pesticides use and limitation of environmental impacts. irstea. hal02587721

Aubry C (2013) L'agriculture urbaine, contributrice des stratégies alimentaires des mégapoles? In: 24èmes Journées Scientifiques de l'Environnement - La transition écologique des mégapoles. Creteil, France. hal-00805185

Aubry C, Kebir L (2013) Shortening food supply chains: a means for maintaining agriculture close to urban areas? The case of the French metropolitan area of Paris. Food Policy 41:85-93. https://doi.org/10. 1016/j.foodpol.2013.04.006

Baize D (1994) Teneurs totales en métaux lourds dans les sols français
Béchet B, Carré F, Florentin L, Leyval C, Montanarella L, Morel J, Raimbault G, Rodriguez F, Rossignol J, Schwartz C (2009) Caractéristiques et fonctionnement des sols urbains. In: Cheverry et Gascuel (éd) Sous les pavés la terre, Omniscience. Montreuil, pp 45-74

Béchet B, Joimel S, Jean-Soro L, Hursthouse A, Agboola A, Leitão TE, Costa H, do Rosário Cameira M, Le Guern C, Schwartz C, Lebeau T (2018) Spatial variability of trace elements in allotment gardens of four European cities: assessments at city, garden, and plot scale. J Soils Sediments 18:391-406. https://doi.org/10.1007/s11368-0161515-1

Beecham S, Razzaghmanesh M (2015) Water quality and quantity investigation of green roofs in a dry climate. Water Res 70:370-384. https://doi.org/10.1016/j.watres.2014.12.015

Bell S, Montarzino A, Travlou P (2007) Mapping research priorities for green and public urban space in the UK. Urban For Urban Green 6: 103-115. https://doi.org/10.1016/j.ufug.2007.03.005

Blanchart A, Séré G, Johan C, Warot G, Stas M, Consalès Jean N, Morel JL, Schwartz C (2018) Towards an operational methodology to optimize ecosystem services provided by urban soils. Landsc Urban Plan 176:1-9. https://doi.org/10.1016/j.landurbplan.2018. 03.019

Bouzouidja R, Sere G, Claverie R, Lacroix D (2013) Characterization of the thermo-hydric functioning of in situ green roof. Houille BlancheRevue International de l'eau 62-69. https://doi.org/10.1051/lhb/ 2013044

Bouzouidja R, Rousseau G, Galzin V, Claverie R, Lacroix D, Séré G (2018a) Green roof ageing or isolatic Technosol's pedogenesis? J Soils Sediments 18:418-425. https://doi.org/10.1007/s11368-0161513-3

Bouzouidja R, Séré G, Claverie R, Ouvrard S, Nuttens L, Lacroix D (2018b) Green roof aging: quantifying the impact of substrate evolution on hydraulic performances at the lab-scale. J Hydrol 564:416423. https://doi.org/10.1016/j.jhydrol.2018.07.032

Bouzouidja R, Bouquet D, Pierart A, Shahid M, Le Guern C, Jean-Soro L, Dumat C, Lebeau T (2019) Metal contamination in urban soils: use of nature-based solutions for developing safe urban cropping. In: Sanchez-Hernandez C (ed) Bioremediation of Agricultural Soils Science Publishers, C. CRC Press, Sanchez-Hernandez, pp 87108. https://doi.org/10.1201/9781315205137-5

Bruand A, Duval O, Cousin I (2004) Estimation des propriétés de rétention en eau des sols à partir de la base de données SOLHYDRO: Une première proposition combianant le type d'horizon, sa texture et sa densité apparente. Etude et gestion des Sols 11:3-323

Bulkeley H, Raven R (2017) Analysing nature-based solutions for urban sustainability: towards a framework for NATURVATION. NATURVATION Deliverable 1:6

Byeon W (2006) A study on the development of design model of ecological park as stormwater storage facilities. J Korea Soc Environ Restor Technol 9:1-16

Cambou A, Shaw RK, Huot H, Vidal-Beaudet L, Hunault G, Cannavo P, Nold F, Schwartz C (2018) Estimation of soil organic carbon stocks of two cities, New York City and Paris. Sci Total Environ 644:452464. https://doi.org/10.1016/j.scitotenv.2018.06.322

Cannavo P, Vidal-Beaudet L, Grosbellet C (2014) Prediction of longterm sustainability of constructed urban soil: impact of high amounts of organic matter on soil physical properties and water transfer. Soil Use Manag 30:272-284. https://doi.org/10.1111/sum.12112

Castrignanò A, Giugliarini L, Risaliti R, Martinelli N (2000) Study of spatial relationships among some soil physico-chemical properties of a field in central Italy using multivariate geostatistics. Geoderma 97:39-60. https://doi.org/10.1016/S0016-7061(00)00025-2

Cerema, MUTK, Ekodenge, LIST, Green4Cities, Acciona, Cartif, Agrocampus Ouest, Szeged University, Nobatek, Plante et Cité 
(2018) D1.1 - NBS multi-scalar and multi-thematic typology and associated database, Nature4Cities H2020 Project Deliverable

Chowdhury A, Pradhan S, Saha M, Sanyal N (2008) Impact of pesticides on soil microbiological parameters and possible bioremediation strategies. Indian J Microbiol 48:114-127

Craul PJ (1992) Urban Soil in Landscape Design. Wiley

Dagois R, Faure P, Bataillard P, Bouzouidja R, Coussy S, Leguédois S, Enjelvin N, Schwartz C (2017) From atmospheric- to pedo-climate modeling in Technosols: a global scale approach. Geoderma 301: 47-59. https://doi.org/10.1016/j.geoderma.2017.04.011

Danielsson L-G, Magnusson B, Westerlund S (1978) An improved metal extraction procedure for the determination of trace metals in sea water by atomic absorption spectrometry with electrothermal atomization. Anal Chim Acta 98:47-57. https://doi.org/10.1016/S00032670(01)83237-2

De Kimpe CR, Morel J-L (2000) Urban soil management: A growing concern. Soil Sci 165:31-40

Defoe PP, Hettiarachchi GM, Benedict C, Martin S (2014) Safety of gardening on lead-and arsenic-contaminated urban brownfields. J Environ Qual 43:2064-2078

Dequiedt S, Saby NPA, Lelievre M, Jolivet C, Thioulouse J, Toutain B, Arrouays D, Bispo A, Lemanceau P, Ranjard L (2011) Biogeographical patterns of soil molecular microbial biomass as influenced by soil characteristics and management. Glob Ecol Biogeogr 20:641-652. https://doi.org/10.1111/j.1466-8238.2010. 00628.x

Dicks L, Haddaway N, Hernández-Morcillo M, Mattsson B, Randall N, Failler P, Ferretti J, Livoreil B, Saarikoski H, Santamaria L, et al (2017) Knowledge synthesis for environmental decisions: an evaluation of existing methods, and guidance for their selection, use and development: a report from the EKLIPSE project

Doick KJ, Sellers G, Castan-Broto V, Silverthorne T (2009) Understanding success in the context of brownfield greening projects: the requirement for outcome evaluation in urban greenspace success assessment. Urban For Urban Green 8:163-178. https://doi. org/10.1016/j.ufug.2009.05.002

Douay F, Pruvot C, Roussel H, Ciesielski H, Fourrier H, Proix N, Waterlot C (2008) Contamination of urban soils in an area of Northern France polluted by dust emissions of two smelters. Water Air Soil Pollut 188:247-260. https://doi.org/10.1007/s11270-0079541-7

Edmondson JL, Davies ZG, McCormack SA, Gaston KJ, Leake JR (2014) Land-cover effects on soil organic carbon stocks in a European city. Sci Total Environ 472:444-453. https://doi.org/10. 1016/j.scitotenv.2013.11.025

European Commission (2016) Communication from the Commission to the European Parliament, the Council, the European Economic and Social Committee and the Committee of The Regions Next Steps for a Sustainable European future - European Action for Sustainability. $\mathrm{COM} / 2016 / 0739$

Faivre N, Fritz M, Freitas T, de Boissezon B, Vandewoestijne S (2017) Nature-based solutions in the EU: innovating with nature to address social, economic and environmental challenges. Environ Res 159: 509-518. https://doi.org/10.1016/j.envres.2017.08.032

Gaston KJ, Ávila-Jiménez ML, Edmondson JL (2013) Managing urban ecosystems for goods and services. J Appl Ecol 50:830-840

Green4cities, MUTK, Cerema, Green4Cities, Agrocampus Ouest, Szeged University, Nobatek, Plante et Cité (2018) D2.1 - System of integrated multi-scale and multithematic performance indicators for the assessment of urban challenges and NBS

Gregory JH, Dukes MD, Jones PH, Miller GL (2006) Effect of urban soil compaction on infiltration rate. J Soil Water Conserv 61:117-124

Haase D, Larondelle N, Andersson E, Artmann M, Borgström S, Breuste J, Gomez-Baggethun E, Gren A, Hamstead Z, Hansen R et al (2014) A quantitative review of urban ecosystem service assessments: concepts, models, and implementation. Ambio 43:413-433
Han F, Banin A, Triplett G (2001) Redistribution of heavy metals in aridzone soils under a wetting-drying cycle soil moisture regime. Soil Sci 166:18-28

Hartley W, Dickinson NM, Riby P, Lepp NW (2009) Arsenic mobility in brownfield soils amended with green waste compost or biochar and planted with Miscanthus. Environ Pollut 157:2654-2662

Hewitt A, Dominati E, Webb T, Cuthill T (2015) Soil natural capital quantification by the stock adequacy method. Geoderma 241-242: 107-114. https://doi.org/10.1016/j.geoderma.2014.11.014

Horrigue W, Dequiedt S, Prévost-Bouré NC, Jolivet C, Saby NP, Arrouays D, Bispo A, Maron P-A, Ranjard L (2016) Predictive model of soil molecular microbial biomass. Ecol Indic 64:203211. https://doi.org/10.1016/j.ecolind.2015.12.004

Huber S, Prokop G, Arrouays D, Banko G, Bispo A, Jones R, Kibblewhite M, Lexer W, Möller A, Rickson R, others (2008) Environmental assessment of soil for monitoring: volume I, indicators \& criteria. Office for the Official Publications of the European Communities, Luxembourg

ISO 10390 (2005) Soil quality, determination of pH. International Organization for Standardization, Geneve, Switzerland

ISO 10693 (1999) NF ISO 10693 - Qualité du sol-Détermination de la teneur en carbonate- Méthode volumétrique

ISO 10694 (1995) NF ISO 10694 - Qualité du sol-Dosage du carbone organique et $\mathrm{du}$ carbone total après combustion sèche (analyse élémentaire)

ISO 11263 (1995) Soil quality-determination of phosphorusspectrometric determination of phosphorus soluble in sodium hydrogen carbonate solution

ISO 13878 (1998) Soil quality, determination of total nitrogen content by dry combustion ("elemental analysis"). International Organization for Standardization, Geneve

IUSS Working Group WRB (2015) World reference base for soil resources 2014, update 2015: International soil classification system for naming soils and creating legends for soil maps. Fao, Rome

Jean-Soro L, Le Guern C, Bechet B, Lebeau T, Ringeard M-F (2015) Origin of trace elements in an urban garden in Nantes, France. J Soils Sediments 15:1802-1812

Jelinkova V, Dohnal M, Sacha J (2016) Thermal and water regime studied in a thin soil layer of green roof systems at early stage of pedogenesis. J Soils Sediments 16:2568-2579. https://doi.org/10.1007/ s11368-016-1457-7

Joimel S, Cortet J, Jolivet CC, Saby NPA, Chenot ED, Branchu P, Consalès JN, Lefort C, Morel JL, Schwartz C (2016) Physicochemical characteristics of topsoil for contrasted forest, agricultural, urban and industrial land uses in France. Sci Total Environ 545:40 47. https://doi.org/10.1016/j.scitotenv.2015.12.035

Joimel S, Grard B, Auclerc A, Hedde M, Le Doaré N, Salmon S, Chenu C (2018) Are Collembola "flying" onto green roofs? Ecol Eng 111: 117-124. https://doi.org/10.1016/j.ecoleng.2017.12.002

Kabata-Pendias A (2010) Trace Elements in Soils and Plants, Fourth. In: CRC Press. https://www.crcpress.com/Trace-Elements-in-Soilsand-Plants-Fourth-Edition/Kabata-Pendias/p/book/ 9781420093681. Accessed 4 Sep 2017

Kabisch N, Frantzeskaki N, Pauleit S, Naumann S, Davis M, Artmann M, Haase D, Knapp S, Korn H, Stadler J, Zaunberger K, Bonn A (2016) Nature-based solutions to climate change mitigation and adaptation in urban areas: perspectives on indicators, knowledge gaps, barriers, and opportunities for action. Ecol Soc 21. https://doi.org/10.5751/ ES-08373-210239

Kahr G, Madsen F (1995) Determination of the cation exchange capacity and the surface area of bentonite, illite and kaolinite by methylene blue adsorption. Appl Clay Sci 9:327-336. https://doi.org/10.1016/ 0169-1317(94)00028-O

Keller C, Robert S, Lambert M, Ajmone Marsan F, Ambrosi J, Biasioli M, Criquet S, Rabot E, et al (2014) Préconisation d'utilisation des sols et qualité des sols en zone urbaine et péri-urbaine-application 
du bassin minier de Provence. In: Journées d'étude des sols (JES). pp 55-56

Kelly C (2003) Acute food insecurity in mega-cities: issues and assistance options. Benfield Hazard Research Centre, London

Kumar K, Hundal LS (2016) Soil in the city: sustainably improving urban soils. J Environ Qual 45:2-8. https://doi.org/10.2134/jeq2015.11. 0589

Kumar A, Nayak AK, Shukla AK, Panda BB, Raja R, Shahid M, Tripathi R, Mohanty S, Rath PC (2012) Microbial biomass and carbon mineralization in agricultural soils as affected by pesticide addition. Bull Environ Contam Toxicol 88:538-542. https://doi.org/10.1007/ s00128-012-0538-6

Lal R (2009) Soil degradation as a reason for inadequate human nutrition. Food Secur 1:45-57

Lal R (2016) Globalizing Environmental Sustainability: "2015 International Year of Soil" Transitioning to "2015-2024 International Decade of Soil.” In: Lal R, Kraybill D, Hansen DO, Singh BR, Mosogoya T, Eik LO (eds) Climate change and multidimensional sustainability in African agriculture: climate change and sustainability in agriculture. Springer International Publishing, Cham, pp 457-466, Globalizing Environmental Sustainability: "2015 International Year of Soil" Transitioning to "2015-2024 International Decade of Soil"

Le Guern C, Baudouin V, Conil P, Courtais B, Houel M, Coffinet A, Latourte C, Gourmelen F (2013) METOTRASS: Méthodologie Optimisée Pour L'évaluation des Teneurs en Éléments Trace (As, $\mathrm{Pb}, \mathrm{Cu}, \mathrm{Zn})$ Dans les Sols En Domaine de Socle: Test sur le Département de la Loire-Atlantique (in French), Final Report, Convention 0972C0030, BRGM/RP-63998-FR. Agence De l'Environnement et de la Maitrise de Energie

Le Guern C, Baudouin V, Sauvaget B, Pineau-Jamin E, Gaubert C, Braud R, Desse-Engrand F, Polett S, Ménoury A, Bodéré G, Milano E, Concil P, Bâlon P (2017) Développement d'une méthodologie de gestion des terres excavées issues de l'aménagement de quartiers nantais - Phase 1 : Caractérisation des sols et recensement des sources de pollution potentielles. Final report, BRGM/RP-67138FR

Le Guern C, Jean-Soro L, Béchet B, Lebeau T, Bouquet D (2018) Management initiatives in support of the soil quality of urban allotment gardens: examples from Nantes (France). Land Degrad Dev 29:3681-3692. https://doi.org/10.1002/ldr.3123

Levin MJ, Kim K-HJ, Morel JL, Burghardt W, Charzynski P, Shaw RK (2017) Soils within Cities. Catena soil sciences, Stuttgart

Liu Z, Yang Y, He C, Tu M (2019) Climate change will constrain the rapid urban expansion in drylands: a scenario analysis with the zoned land use scenario dynamics-urban model. Sci Total Environ 651:2772-2786. https://doi.org/10.1016/j.scitotenv.2018.10.177

Mentens J, Raes D, Hermy M (2006) Green roofs as a tool for solving the rainwater runoff problem in the urbanized 21 st century? Landsc Urban Plan 77:217-226. https://doi.org/10.1016/j.landurbplan. 2005.02.010

Minzenmayer FE (1979) Soil survey of Jim Wells County. Texas.

Mohtar RH, Lawford R (2016) Present and future of the water-energyfood nexus and the role of the community of practice. J Environ Stud Sci 6:192-199

Morel JL, Séré G, Auclerc A, Schwartz C, Leguédois C (2014) Watteau F. Soils in urban environments: characteristics, services and problems of their investigation. SSP Congrès Annuel, Changins, Switzerland

Morel J, Schwartz C, Florentin L, De Kimpe C (2005) Urban soils. Encycl Soils Environ 4:202-208. https://doi.org/10.1016/b0-12348530-4/00305-2

Morel JL, Chenu C, Lorenz K (2015) Ecosystem services provided by soils of urban, industrial, traffic, mining, and military areas (SUITMAs). J Soils Sediments 15:1659-1666. https://doi.org/10. 1007/s11368-014-0926-0
Nature4Cities (2016) Nature4Cities project. https://www.nature4cities. eu/. Accessed 30 Jan 2020

Pateraki S, Manousakas M, Bairachtari K, Kantarelou V, Eleftheriadis K, Vasilakos C, Assimakopoulos VD, Maggos T (2019) The traffic signature on the vertical PM profile: environmental and health risks within an urban roadside environment. Sci Total Environ 646:448 459. https://doi.org/10.1016/j.scitotenv.2018.07.289

Pereira P, Bogunovic I, Muñoz-Rojas M, Brevik EC (2018) Soil ecosystem services, sustainability, valuation and management. Curr Opin Environ Sci Health 5:7-13. https://doi.org/10.1016/j.coesh.2017.12. 003

Pouyat RV, Szlavecz K, Yesilonis ID, Groffman PM, Schwarz K (2010) Chemical, physical, and biological characteristics of urban soils. In: Urban Ecosystem Ecology (Agronomy Monograph), Urban Ecosystem Ecology. Agronomy. Aitkenhead-Peterson, Jacqueline; Volder, Astrid, pp 119-152

Rawles WJ, Brakensiek D (1982) Estimating soil water retention from soil properties. J Irrig Drain Div 108:166-171

Rawles W, Gish T, Brakensiek D (1991) Estimating soil water retention from soil physical properties and characteristics. In: Stewart BA (ed) Advances in Soil Science. Springer, New York, pp 213-234

Rawlins B, Harris J, Price S, Bartlett M (2015) A review of climate change impacts on urban soil functions with examples and policy insights from England, UK. Soil Use Manag 31:46-61

Raymond CM, Berry P, Breil M, Nita MR, Kabisch N, de Bel M, Enzi V, Frantzeskaki N, Geneletti D, Cardinaletti M, Lovinger L, Basnou C, Monteiro A, Robrecht H, Sgrigna G, Munari L, Calfapietra C (2017) An impact evaluation framework to support planning and evaluation of nature-based solutions projects - Climate-ADAPT. Centre for Ecology \& Hydrology, Wallingford

Rees F, Dagois R, Derrien D, Fiorelli J-L, Watteau F, Morel JL, Schwartz C, Simonnot M-O, Séré G (2019) Storage of carbon in constructed technosols: in situ monitoring over a decade. Geoderma 337:641648. https://doi.org/10.1016/j.geoderma.2018.10.009

Scharenbroch BC, Lloyd JE, Johnson-Maynard JL (2005) Distinguishing urban soils with physical, chemical, and biological properties. Pedobiologia 49:283-296. https://doi.org/10.1016/j.pedobi.2004. 12.002

Schrader S, Böning M (2006) Soil formation on green roofs and its contribution to urban biodiversity with emphasis on Collembolans. Pedobiologia 50:347-356. https://doi.org/10.1016/j.pedobi.2006. 06.003

Schwager J, Schaal L, Simonnot M-O, Claverie R, Ruban V, Morel J-L (2015) Emission of trace elements and retention of $\mathrm{Cu}$ and $\mathrm{Zn}$ by mineral and organic materials used in green roofs. J Soils Sediments 15:1789-1801. https://doi.org/10.1007/s11368-014-0962-9

Schwartz C, Fetzer K, Kubiniok J, Morel J (2000) Availability of pollutants in garden soils. In: Proceedings of the First International Conference on Soils of Urban, Industrial, Traffic and Mining Areas (SUITMA), Burghardt, W. et Dornauf. C. Eds, Essen, pp 485-490

Séré G, Ouvrard S, Magnenet V, Pey B, Morel JL, Schwartz C (2012) Predictability of the evolution of the soil structure using water flow modeling for a constructed. Technosol Vadose Zone J:11. https:// doi.org/10.2136/vzj2011.0069

Simmons MT, Gardiner B, Windhager S, Tinsley J (2008) Green roofs are not created equal: the hydrologic and thermal performance of six different extensive green roofs and reflective and non-reflective roofs in a sub-tropical climate. Urban Ecosyst 11:339-348. https:// doi.org/10.1007/s11252-008-0069-4

Sněhota M, Hanzliková J, Heckova P, Sacha J, Jelinkova V, Kaestner A (2019) Effects of early structural changes of engineered soils on green roof and bioretention performance. IOP Conf Ser Earth Environ Sci 290:012086. https://doi.org/10.1088/1755-1315/290/1/ 012086 
Sněhota M, Hanzlíková J, Sobotková M, Moravcik P (2020) Water and thermal regime of extensive green roof test beds planted with sedum cuttings and sedum carpets. Submitted to this issue of Journal of Soils and Sediments

United Nations (2018) 2018 Revision of World Urbanization Prospects | Multimedia Library - United Nations Department of Economic and Social Affairs

Vidal-Beaudet L, Cannavo P, Schwartz C, Séré G, Bechet B, Legret M, Peyneau PE, Bataillard P, Coussy S, Damas O (2017) Using wastes for fertile urban soil construction-the French Research Project SITERRE. In: Soils within Cities - Global approaches to their sustainable management - composition, properties, and functions of soils of the urban environment. p 253

Voigt A, Latkowska M, Rutecka A, Poniży L, Mizgajski A, Breuste J, et al (2015) Environmental behavior of urban allotment gardeners in Europe. Landscapes in flux Estonian University of Life Sciences, Estonia 78-82

Volchko Y, Norrman J, Bergknut M, Rosén L, Söderqvist T (2013) Incorporating the soil function concept into sustainability appraisal of remediation alternatives. J Environ Manag 129:367-376
Vrščaj B, Poggio L, Marsan FA (2008) A method for soil environmental quality evaluation for management and planning in urban areas. Landsc Urban Plan 88:81-94

Watt A, Ainsworth G, Balian E, Cojocaru G, Darbi M, Dicks L, Eggermont H, Furman E, Goudeseune L, Huybrecht P, Kelemen E, Koch F, Konstantinou Z, Livoreil B, Locher K, Lux A, Mehring M, Nesshoever C, Paloniemi R, Saarikoski H, Pinto IS, Vandewalle M, Varjopuro R, Varumo L, Wittmer H, Young J (2019) EKLIPSE: engaging knowledge holders and networks for evidence-informed European policy on biodiversity and ecosystem services

Wei B, Jiang F, Li X, Mu S (2008) Heavy metal induced ecological risk in the city of Urumqi, NW China. Environ Monit Assess 160:33-45. https://doi.org/10.1007/s10661-008-0655-1

Wołejko E, Jabłońska-Trypuć A, Wydro U, Butarewicz A, Łozowicka B (2019) Soil biological activity as an indicator of soil pollution with pesticides - a review. Appl Soil Ecol:103356. https://doi.org/10. 1016/j.apsoil.2019.09.006

Publisher's note Springer Nature remains neutral with regard to jurisdictional claims in published maps and institutional affiliations. 